\title{
Development of muffin with the incorporation of olive pomace flour, extra virgin olive oil and hydrolyzed soy protein
}

\author{
Desenvolvimento de muffin com a incorporação de farinha de bagaço de oliva, azeite de oliva \\ extravirgem e proteína hidrolisada de soja \\ Elaboración de un muffin con la incorporación de harina de orujo de oliva, aceite de oliva extra
} virgen y proteína de soja hidrolisada

Received: 01/21/2022 | Reviewed: 01/27/2022 | Accept: 02/04/2022 | Published: 02/06/2022

Edneia Correia de Souza

ORCID: https://orcid.org/0000-0002-0163-7113 Federal University of Jequitinhonha and Mucuri Valleys, Brazil E-mail: edneiasouza505@gmail.com

Daniela Alves Cordeiro

ORCID: https://orcid.org/0000-0002-7204-3304 Federal University of Jequitinhonha and Mucuri Valleys, Brazil E-mail: daniela.alves@ufvjm.edu.br

Bruna Sanches Silva

ORCID: https://orcid.org/0000-0003-0044-2282 Federal University of Jequitinhonha and Mucuri Valleys, Brazil E-mail: brs.sanches@hotmail.com

Nathália de Andrade Neves

ORCID: https://orcid.org/0000-0001-6936-2171 Federal University of Jequitinhonha and Mucuri Valleys, Brazil E-mail: nathalia.neves@ict.ufvjm.edu.br

Marcio Schmiele

ORCID: https://orcid.org/0000-0001-8830-1710 Federal University of Jequitinhonha and Mucuri Valleys, Brazil E-mail:marcio.sc@ict.ufvjm.edu.br

\begin{abstract}
Olive pomace flour, extra virgin olive oil and hydrolyzed soy protein are ingredients rich in compounds with beneficial health properties, such as phenolic compounds, dietary fiber, amino acids and fatty acids. In this sense, the present study aimed to evaluate the influence of partial replacement of wheat flour, hydrogenated vegetable fat and sucrose by olive pomace flour, extra virgin olive oil and hydrolyzed soy protein, respectively, in muffin-type cakes. The determination of the ideal formulation with the alternative ingredients was carried out through the Response Surface Methodology, exploring a Simplex-Centroid Mixture Design using physicochemical parameters as dependent variables. The optimum point was obtained using $38.00 \%$ olive pomace flour, $3.75 \%$ extra virgin olive oil, and 4.05 $\%$ hydrolyzed soy protein. In general, it was observed that the alternative ingredients had positive effects on the texture profile of the muffins and provided products with darker shades, characteristics of the ingredients used. Nutritionally, an increase in total dietary fiber, ash and lipid content was observed. In contrast, the starch content decreased, but the total caloric value was similar between the standard sample and the optimum. Therefore, the partial replacement of ingredients demonstrated feasibility and potential for bakery goods.
\end{abstract}

Keywords: Amino acids; Bakery; Cakes; Dietary fibers; Firmness; Phenolic compounds.

\section{Resumo}

A farinha de bagaço de oliva, o azeite de oliva extravirgem e a proteína hidrolisada de soja são ingredientes ricos em compostos com propriedades benéficas à saúde, como os compostos fenólicos, as fibras alimentares, os aminoácidos e os ácidos graxos. Nesse sentido, o presente estudo teve como objetivo avaliar a influência da substituição parcial da farinha de trigo, gordura vegetal hidrogenada e sacarose por farinha de bagaço de oliva, azeite de oliva extravirgem e proteína hidrolisada de soja, respectivamente, em bolos tipo muffin. A determinação da formulação ideal com os ingredientes alternativos foi realizada por meio da Metodologia de Superfície de Resposta, explorando um Planejamento de Mistura Simplex-Centroid utilizando parâmetros físico-químicos como variáveis dependentes. O ponto ótimo foi obtido com 38,00 \% de farinha de bagaço de oliva, 3,75\% de azeite de oliva extravirgem e 4,05\% de proteína hidrolisada de soja. De maneira geral, observou-se que os ingredientes alternativos tiveram efeitos positivos no perfil de textura dos muffins e proporcionaram produtos com tonalidades mais escuras, características dos ingredientes utilizados. Nutricionalmente, observou-se aumento no teor de fibra alimentar total, cinzas e lipídios. Em 
contrapartida, o teor de amido diminuiu, mas o valor calórico total foi semelhante entre a amostra padrão e a ótima. Portanto, a substituição parcial de ingredientes demonstrou viabilidade e potencial para produtos de panificação.

Palavras-chave: Aminoácidos; Bolos; Compostos fenólicos; Fibras alimentares; Firmeza; Panificação.

\section{Resumen}

La harina de orujo de oliva, el acete de oliva virgen extra y la proteia hidrolisada de soja son ingredientes ricos en compuestos con propriedades beneficiosas para la salud, como compuestos fenólicos, fibra dietética, aminoácidos y ácidos grasos. En este sentido, el presente estudio tuvo por objetivo evaluar la influencia de la sustitución parcial de harina de trigo, grasa vegetal hidrogenada y sacarosa, por harina de orujo de oliva, aceite de oliva virgen extra y proteína de soja hidrolizada, respectivamente, en muffins. La determinación de la formulación ideal con los ingredientes alternativos se realizó mediante la Metodología de Superficie de Respuesta, explorando una Planificación de Mezcla Simplex-Centroid utilizando parámetros fisicoquímicos como variables dependientes. El punto óptimo se obtuvo con un $38,00 \%$ de harina de orujo de oliva, un 3,75\% de aceite de oliva virgen extra y un 4,05\% de proteína de soja hidrolizada. En general, se observó que los ingredientes alternativos tuvieron efectos positivos en el perfil de textura de los muffins y dotaron a los productos de tonalidades más oscuras, propias de los ingredientes utilizados. Nutricionalmente, hubo un aumento en el contenido de fibra dietética total, cenizas y lípidos. En contrapartida, el contenido de almidón disminuyó, pero el valor calórico total fue similar entre las muestras estándar y óptima. Sin embargo, la sustitución parcial de ingredientes demostró la viabilidad y el potencial de los productos de panadería.

Palabras clave: Aminoácidos; Compuestos fenólicos; Fibras alimenticias; Firmeza; Panadería; Pasteles.

\section{Introduction}

The muffin-type cake, similar to cupcakes, is a small-sized and ready-made cake sold in individual packages for consumption as a snack or in meals (Scarton et al., 2021). Ready-to-eat products have many consumers looking for foods that provide practicality, sensoriality and pleasure (Souza \& Schmiele, 2021). According to the Brazilian Association of Biscuit, Pasta, Bread \& Industrialized Cakes Industries (ABIMAPI), cakes grew by $72 \%$ in Brazil, compared 2020 to 2019. It occurs following the trend of consumers who have been interested in convenient and affordable products that do not require a lot of time to prepare at home and are economically viable (ABIMAPI, 2021). In 2019, 82,159 tons of industrialized cakes were produced, with approximately R 354 million turnovers (IBGE, 2019).

Muffins have high consumer acceptability due to their sweet taste, soft texture, and moistened mouthfeel (Goswami et al., 2015). The alveolar and aerated spongy texture is attributed to the porous structure formed by the incorporation of air during the mixing stage of the batter, the release of $\mathrm{CO}_{2}$ and the expansion of water vapor and gases during the baking step. The increase in the specific volume of cakes occurs due to the expansion of the small air bubbles trapped in the batter. This condition is only possible because the cake production consists of an emulsion where the lipids correspond to the dispersed phase and the water composes the continuous phase. Air trapping in the batter is favored by adding egg, sucrose and emulsifiers to the fat in shortenings-based cakes (Martínez-Cervera et al., 2012).

As they are convenient and sensorially appreciated products, muffins can represent potential matrices to add nutritional, technological and physiological values. However, changing the formulation and developing a new product requires attention to preserving the technical characteristics (Aranibar et al., 2019). Muffins have a very variable composition. However, the formulation is characterized by a large amount of flour, sugar and fat. The partial replacement of these ingredients can improve the nutritional quality of the cakes. Vegetable bagasse flour differentiated lipid sources and legume protein are promising alternatives.

Olive oil is the only part extracted from olives (Olea europea L.) and characterized as an aromatic, green to greenish-yellow in color and translucent liquid. The most common processes for obtaining olive oil are (i) discontinuous processes (using mills and presses) or (ii) continuous processes (two-phase or three-phase system). The discontinuous extraction is carried out by harvesting, washing and crushing the olives in a mill. The paste obtained after milling goes through a process of malaxation and subsequent pressing to recover two phases: the liquid (composed of oil and vegetation water) and the solid (contained the bagasse with high water content). Finally, the liquid phase goes through a centrifugation step to 
remove impurities and vegetation water from the oil. In continuous extraction, the number of residues can vary due to a higher or lower amount of water in the process. In the two-phase system, only olive pomace is obtained as waste, while in the threephase system, pomace and wastewater from the olive crushing are recovered (Marx et al., 2021; Nunes et al., 2016; Rodrigues et al., 2015; Silva \& Schmiele, 2021). Regarding the nutritional quality, olive oils have a varied composition, presenting about 230 compounds such as aliphatic and triterpene alcohols, sterols, hydrocarbons, volatile compounds and phenolic compounds. The olive varieties grown in Brazil have a varied profile of 19 phenolic compounds from the phenolic alcohols, lignans, secoiridoids and flavonoids classes (Ballus et al., 2015).

According to Silva (2020), the extra virgin olive oil of the $c v$. Barnea (harvest 2018) produced in Vale do Jequitinhonha (State of Minas Gerais) has an excellent state of conservation with a low peroxide index ( $4.58 \mathrm{meq} . \mathrm{O}_{2} / \mathrm{kg}$ ) and specific extinction coefficients $\left(\mathrm{K}_{232}=1.46 \pm 0.06 ; \mathrm{K}_{270}=0.13 \pm<0.01\right)$, representing a low degree of oxidation. In addition, it has a high concentration of total phenolic compounds (14.72 mg of gallic acid.100 $\mathrm{g}^{-1}$ of oil), high content of monounsaturated fatty acids (MUFA), low levels of polyunsaturated (PUFA) and saturated fatty acids, and a high smoke point $\left(\sim 216 \pm 2.16^{\circ} \mathrm{C}\right)$. For these reasons, the author inferred that olive oil from the Barnea variety is suitable for food processing when high temperatures, such as baking, are applied. As for the fatty acids present in olive oil from $c v$. Barnea, the following contents were identified: palmitic acid $(9.14 \pm 0.39 \%)$; palmitoleic acid $(0.11 \pm 0.04 \%)$; 10-heptadecanoic acid $(0.02 \pm<0.01 \%)$; stearic acid $(0.83 \pm 0.03 \%)$; oleic acid $(86.99 \pm 0.54 \%)$; linoleic acid $(2.07 \pm 0.16 \%)$; $\gamma$-linolenic acid $(0.11 \pm<0.01 \%) ; \alpha$ linolenic acid $(0.26 \pm 0.01 \%)$; and gadolinic acid $(0.16 \pm 0.01 \%)$ (Silva et al., 2019).

Olive pomace is the main residue generated after oil extraction, composed of the epicarp, mesocarp and endocarp of the olives, with significant residual lipids and moisture content. The chemical composition of bagasse is variable due to several factors, such as the cultivation region, soil type, climate, rainfall, varieties and extraction method. However, its composition includes the significant presence of carbohydrates, proteins, fatty acids, minerals, vitamins, pigments and bioactive compounds, especially the phenolic compounds (Lechhab, Lechhab, Cacciola, \& Salmoun, 2022; Medeiros, Villa, Silva, \& Júlio, 2016; Rodrigues et al., 2015). Most of the phenolic compounds ( 98\%) are composed of secoiridoids (glycosylated oleuropein), phenolic alcohols (tyrosol and hydroxytyrosol), hydroxycinnamic acid (verbascoside) and flavonoids (quercetin as flavonols; luteolin-7-O-glucoside, apigenin-7-O-glucoside and diosmetin-7-O-glucoside as flavones) (Ballus et al., 2015; Clodoveo, Crupi, Annunziato, \& Corbo, 2021; Expósito-Díaz et al., 2022; Silva \& Schmiele, 2021) (Figure 1) and remain in the bagasse, which can be a natural and low-cost source for use in the food industry as bioactive ingredients (Nunes et al., 2019). 
Figure 1 - Main phenolic compounds found in olives.

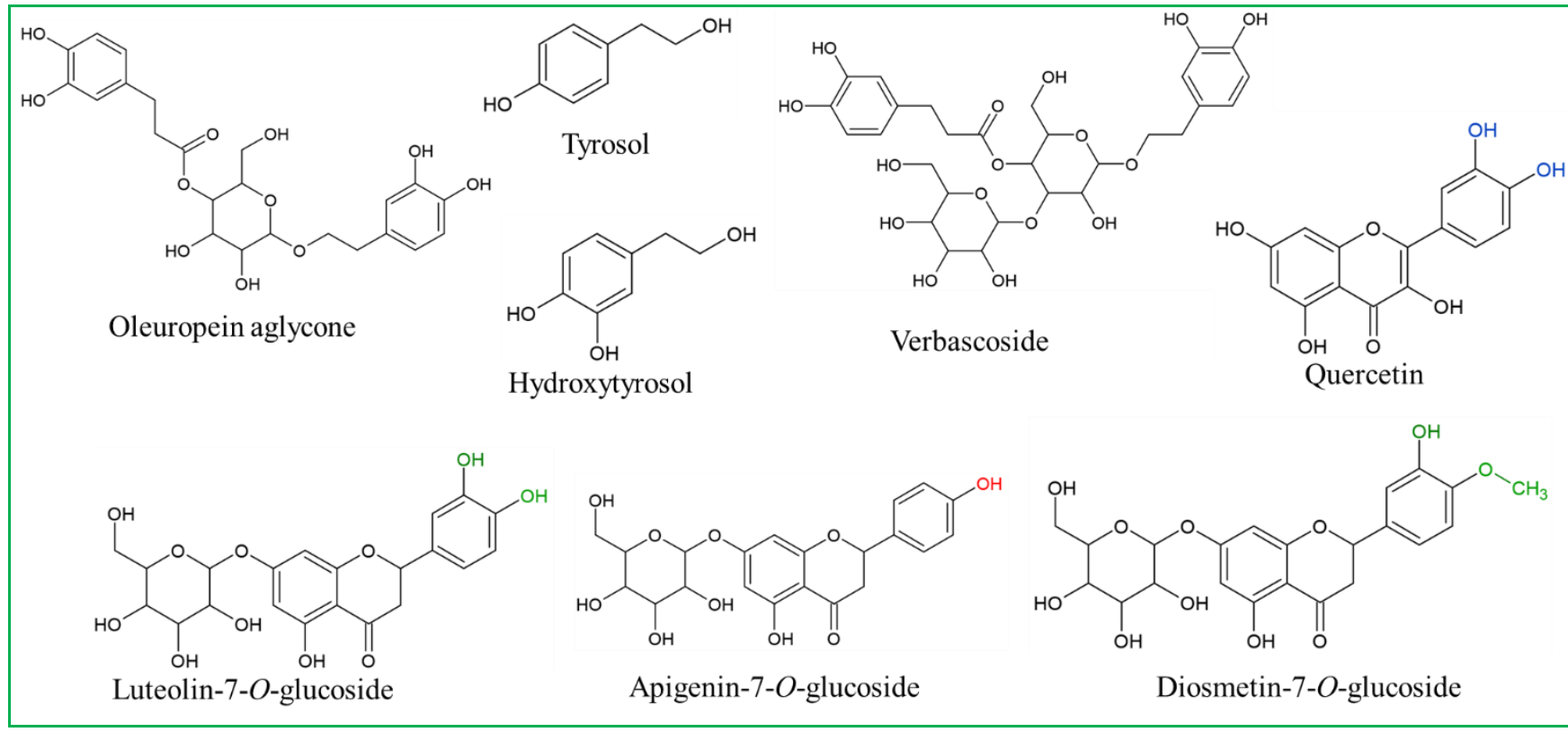

Chemical structures elaborated with ACD/ChemSketch free software. Source: Authors (2022).

The technological application of olive residue requires that the pomace be dehydrated before use to a moisture content of less than $15 \%$ on a dry basis, to avoid product deterioration by bacteria and fungi (mainly molds). Conventional hot air drying stands out among the most common drying techniques used for this purpose. This type of drying allows better control of process parameters and the low temperatures operated are a way of protecting bioactive compounds against degradation processes (Ahmad-Qasem et al., 2013; Sinrod et al., 2019). In addition, olive pomace can be used in flour form to develop new products, being applied mainly in bakery products. According to a study developed by Cedola et al. (2020), bread and spaghetti enriched with olive pomace significantly improved the chemical quality of the formulated pasta. According to Nunzio et al. (2020), partially defatted olive pomace caused a significant increase in the content of phenolic compounds and sterols, especially $\beta$-tocopherol, in all products applied (biscuit, conventionally fermented bread and bread fermented with lactic acid bacteria (L. plantarum 98A, L. sanfranciscensis BB12, L. brevis 3BHI) and S. cerevisiae LBS). The authors argue that both enrichment and the manufacturing process influence the physical-chemical and technological characteristics of the final product. Nunzio et al. (2020) used olive pomace in sensorially adequate concentrations so that the final product has a balanced sensorial profile. For Lin et al. (2017), olive pomace proved to be an excellent alternative for producing Chinese cookies with a high content of dietary fiber.

When unconventional flours are used to replace wheat flour in baked goods, there is a decrease in protein content. Furthermore, cereals are rich in sulfur amino acids (methionine and cysteine) and relatively low in lysine and tryptophan. The reverse is true for legume proteins such as soybeans, beans, peas, lentils, and chickpeas (Damodaran \& Parking, 2017; Wong, 2018).

According to the Brazilian Society of Food and Nutrition, one of the most explored vegetable protein sources in food is soy protein. This isolated protein is made from defatted soy flour through a process that enables the removal of other components, such as carbohydrates, fibers and anti-nutritional factors, representing the most refined and pure form of soy protein. Furthermore, the content of the compounds responsible for the characteristic flavor of soy (sometimes characterized as off-flavor bean flavor) is reduced during the production process of the isolated soy protein, favoring obtaining a product with a more neutral taste and odor. Also, during the processing of isolated soy protein, the anti-nutritional factors present in the grain 
are inactivated, preserving the quality of the protein. Due to these characteristics, its application in foods and diverse ingredients is interesting (SBAN, 2016). In addition, the application of hydrolyzed proteins has been gaining attention due to their beneficial health properties. Currently, proteins can be hydrolyzed by biotechnological methods such as enzymatic, fermentative, or germination. In addition, physical processes such as thermoplastic extrusion (Leal et al., 2021; Ma et al., 2018), hydrothermal treatment (Liang et al., 2020), and ultrasound (Hayta et al., 2020) has been applied as a pretreatment to favor the enzymatic action due to the denaturation of the quaternary and tertiary structures of vegetable proteins, favoring hydrodynamic (gelling) and surfactant (emulsification and aeration) properties (Mozafarpour et al., 2019; Santos et al., 2022). In addition, legume-derived hydrolysates and peptides may exhibit several biofunctions, such as antioxidant, hypolipidemic, antihypertensive, anticancer and anti-inflammatory properties and immunomodulatory effects, reducing chronic noncommunicable diseases and oxidative stress (Ashaolu, 2020; Matemu et al., 2021).

The production and consumption of olive oil are very traditional in the Mediterranean area. Still, they have been gaining ground in several countries, such as the United States, Australia, Canada, Chile, Uruguay, Brazil and China. In Brazilian territory, the states of Rio Grande do Sul (in the pampa), Minas Gerais, Rio de Janeiro and São Paulo (encompassing the Serra da Mantiqueira), Espírito Santo and Bahia (Chapada Diamantina) stand out in terms of production, with about 7000 hectares destined for olive trees (Filoda et al., 2021). The production of olive oil in Brazil contributes to widespread consumption, a factor of great nutritional interest. In this way, the elaboration of products from olive oil and extraction byproducts such as olive pomace can contribute to the diversification of the economy in the producing centers, increasing the offer of products with added value, diversifying the forms of consumption, and increasing the consumption of olive oil in the Brazilian population (Neves et al., 2021).

In this work, we aimed to apply olive pomace flour, extra virgin olive oil and hydrolyzed soy protein in the formulation of muffins, partially replacing refined wheat flour, hydrogenated vegetable fat and sucrose, respectively. The evaluation consisted of the physicochemical properties of the batter and the muffin. In addition, the standard formulation and the optimal point were evaluated for structural and nutritional properties.

\section{Methodology}

This research was carried out in stages through a laboratory and experimental study with quantitative data analysis proposed by Pereira et al. (2018). A general overview regarding the methodology applied is presented in Figure 2. 
Figure 2 - Representative scheme of the methodology.

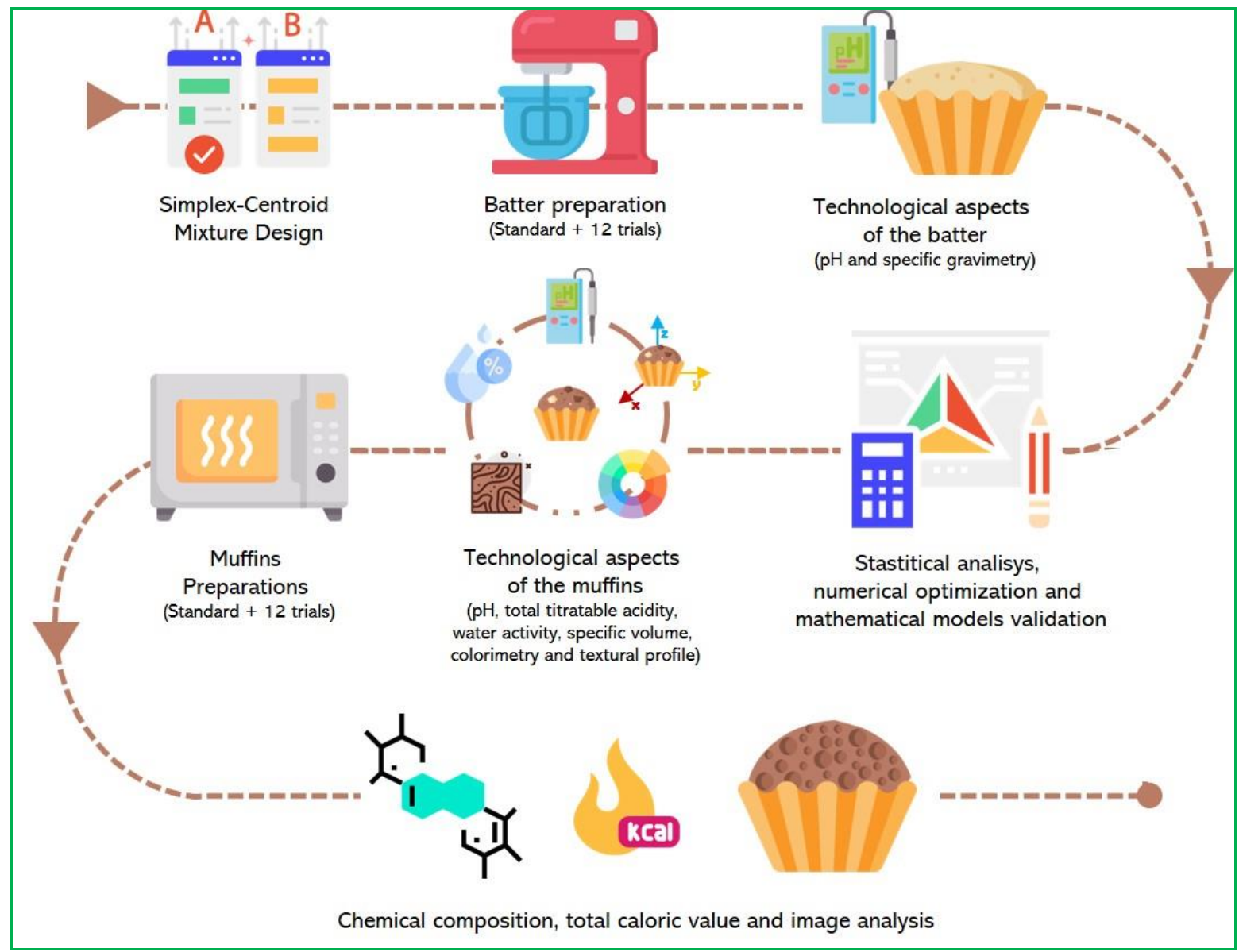

Icons obtained from FlatIcon ${ }^{\circledR}$. Available at https://www.flaticon.com. Source: Authors (2022).

\subsection{Materials}

The ingredients used were wheat flour, sucrose, in natura whole egg, whole UHT milk, hydrogenated vegetable fat, baking powder (sodium bicarbonate, calcium carbonate and monocalcium phosphate and corn starch as a vehicle), emulsifier (distilled monoglycerides, potassium stearate, sorbitan monostearate and polyoxyethylene sorbitan monostearate), olive pomace flour, hydrolyzed soy protein and extra virgin olive oil. Olive pomace flour and extra virgin olive oil were obtained from the $c v$. Barnea, an olive cultivated and harvested at the Federal University of Jequitinhonha and Mucuri Valleys, JK campus (Diamantina, MG). Olive pomace flour was obtained by drying in an oven with circulation and renewal forced air at $80^{\circ} \mathrm{C}$ and extra virgin olive oil was extracted as in a previous study carried out by our research group (Silva, 2020).

\subsection{Standard formulation}

The standard formulation was composed of the following concentrations: refined wheat flour (100\%), sucrose (58.75 $\%)$, in natura whole eggs (50\%), whole UHT milk (45\%), hydrogenated vegetable fat (40\%), baking powder (2.5\%) and emulsifier $(1 \%)$, in flour basis.

\subsection{Design experimental}

The amount of olive pomace flour $(0-50 \%)$, extra virgin olive oil $(0-50 \%)$ and hydrolyzed soy protein $(0-25 \%)$ as partial substitutes for wheat flour, hydrogenated vegetable fat and sucrose, respectively. The study was conducted through the Response Surface Methodology using a Simplex-Centroid Mixture Design (Table 1) (Rodrigues \& Iemma, 2014). A 
sample without the substituents was used as a standard.

Table 1 - Coded and real levels of olive pomace flour, soy protein hydrolysate and extra virgin olive oil for the simplexcentroid mixture design matrix for formulating the muffins.

\begin{tabular}{|c|c|c|c|c|c|c|}
\hline \multirow{2}{*}{ Trial } & \multicolumn{3}{|c|}{ Coded value } & \multicolumn{3}{|c|}{ Real value (\%) } \\
\hline & $\mathrm{x}_{1}$ & $\mathrm{X}_{2}$ & $\mathrm{x}_{3}$ & $\mathrm{X}_{1}$ & $\mathrm{X}_{2}$ & $\mathrm{X}_{3}$ \\
\hline 1 & 1.000 & 0.000 & 0.000 & 50.00 & 0.00 & 0.00 \\
\hline 2 & 0.000 & 1.000 & 0.000 & 0.00 & 25.00 & 0.00 \\
\hline 3 & 0.000 & 0.000 & 1.000 & 0.00 & 0.00 & 50.00 \\
\hline 4 & 0.500 & 0.500 & 0.000 & 25.00 & 12.50 & 0.00 \\
\hline 5 & 0.500 & 0.000 & 0.500 & 25.00 & 0.00 & 25.00 \\
\hline 6 & 0.000 & 0.500 & 0.500 & 0.00 & 12.50 & 25.00 \\
\hline 7 & 0.667 & 0.167 & 0.167 & 33.35 & 4.18 & 8.35 \\
\hline 8 & 0.167 & 0.667 & 0.167 & 8.35 & 16.68 & 8.35 \\
\hline 9 & 0.167 & 0.167 & 0.667 & 8.35 & 4.18 & 33.35 \\
\hline 10 & 0.333 & 0.333 & 0.333 & 16.65 & 8.32 & 16.65 \\
\hline 11 & 0.333 & 0.333 & 0.333 & 16.65 & 8.32 & 16.65 \\
\hline 12 & 0.333 & 0.333 & 0.333 & 16.65 & 8.32 & 16.65 \\
\hline
\end{tabular}

Where: $\mathrm{x}_{1}$ and $\mathrm{X}_{1}$ - olive pomace flour; $\mathrm{x}_{2}$ and $\mathrm{X}_{2}$ - extra virgin olive oil; $\mathrm{x}_{3}$ and $\mathrm{X}_{3}$ - hydrolyzed soy protein. Source: Authors (2021).

\subsection{Preparation of batter and muffins}

The batter for the muffins was prepared in 2 stages using the Orbit Kitchen 600 planetary mixer (Cadence, Balneário Piçarras, BRA), mixing the ingredients according to the standard formulations and the trials from experimental design (Table 1). The first stage, called the cream phase, consisted of mixing the hydrogenated vegetable fat, extra virgin olive oil, sucrose, hydrolyzed soy protein and emulsifier at speed three for $3 \mathrm{~min}$. Then, the in natura whole eggs, previously manually homogenized using a fork, were incorporated at the same speed and time as the previous one. The wire-type whisk was used for the cream phase. In the second stage, called the dough phase, refined wheat flour, UHT whole milk and olive pomace flour were added, mixing the dough at speed one until the ingredients were homogenized (visually observed) using a coated flat beater. Finally, the baking powder was added to the mixture carried out at speed 1 for 20 seconds. The batter was divided into $50 \pm 1 \mathrm{~g}$ portions in paper regency wraps and placed in aluminum baking cups. Then, the batters were baked in a preheated ConventionLine oven (Venâncio, Venâncio Aires, BRA) at $170 \pm 2{ }^{\circ} \mathrm{C}$ for 25 minutes, cooled at room temperature for 2 hours and stored in high-density polyethylene packages at room temperature for the analysis for quantification of dependent variables until the following day. The muffins were mechanically sliced in an FPV12 slicer (Venâncio, Venâncio Aires, BRA) and slices with $12 \mathrm{~mm}$ thickness were obtained.

\subsection{Technological and physicochemical aspects of the batters}

\subsubsection{Specific gravity}

The specific gravity of the batter was evaluated in triplicate according to the American Association of Cereal Chemists International (AACCI) by the method 55-50.01 (AACCI, 2010). The results were expressed in $\mathrm{g} . \mathrm{cm}^{-3}$.

\subsection{2 pH}

The pH was determined using the method 981.12 of the Association of Official Analytical Chemists (AOAC, 2019) through a mPA210 benchtop potentiometer (Tecnopon, Piracicaba, BRA). The analysis was performed in triplicate. 


\subsection{Technological and physicochemical aspects of the muffins}

\subsection{1 $\mathrm{pH}$ and total titratable acidity}

The $\mathrm{pH}$ (method 981.12) and total titratable acidity (method 942.15) were determined according to the AOAC methodology (AOAC, 2019). The analyzes were performed in triplicate.

\subsubsection{Water activity}

The determination of water activity was performed by direct measurement, with three replications, in an Aqualab 4TE Duo hygrometer (Decagon, Pullman, USA) according to the methodology described by (Silva, Rosa, Neves, Leoro, \& Schmiele, 2021).

\subsubsection{Specific volume}

The specific volume was analyzed by the millet seed displacement approach, as established by the method 10-05.01 (AACCI, 2010). The analysis was performed in triplicate and the results were expressed in $\mathrm{cm}^{3} \cdot \mathrm{g}^{-1}$.

\subsubsection{Instrumental color}

The instrumental color of the crumb of the muffins and the raw materials (refined wheat flour, hydrogenated vegetable fat, sucrose, olive pomace flour, extra virgin olive oil and hydrolyzed soy protein) was determined in a CM-5 Konica spectrophotometer (Minolta, Chiyoda, JAP) evaluating the CIE- $L^{*} a^{*} b^{*}$ system and the color variation ( $\triangle \mathrm{E}-$ obtained through Equation 1), with three repetitions. The equipment conditions were configured with illuminant D65, observation angle of $10^{\circ}$ and calibration in RSIN (Reflectance Specular Included) mode, as described by Silva et al. (2021).

$$
\Delta \mathrm{E}=\left[\left(\Delta L^{*}\right)^{2}+\left(\Delta a^{*}\right)^{2}+\left(\Delta b^{*}\right)^{2}\right]^{0,5}
$$

Eq. 1

\subsubsection{Texture profile analysis}

The instrumental texture of the crumb from the muffin was evaluated using method 74-09.01 (AACCI, 2010) in a TA-XT Plus texturometer (Stable Micro Systems, Godalming, GBR). The test conditions established were P/36R cylindrical probe, HDP/90 platform and compression mode, with pre-test speed of $1.0 \mathrm{~mm} \cdot \mathrm{s}^{-1}$, test speed of $1.0 \mathrm{~mm} . \mathrm{s}^{-1}$, post-test speed of $5.0 \mathrm{~mm} . \mathrm{s}^{-1}$, distance of $40 \%$, time between cycles of $1 \mathrm{~s}$ and limiar force of $0.049 \mathrm{~N}$. The analysis was performed with ten repetitions, using two slices of muffins at each repetition. The parameters recalled were firmness $(\mathrm{N})$, hardness $(\mathrm{N})$, cohesiveness (\%), elasticity $(\%)$, gumminess $(\mathrm{N})$, chewiness $(\mathrm{N})$ and resilience $(\%)$.

\subsubsection{Chemical composition of muffins and raw materials and total caloric value of muffins}

The chemical composition of the muffins (standard and optimal point) was obtained by determining the amounts of moisture (method 44-15.02), ash (method 08-01.01), proteins (method 46-13.01; $\mathrm{N}=5.70$ for refined wheat flour and muffins, and $\mathrm{N}=6.25$ for olive pomace flour and hydrolyzed soy protein) and lipids (method 30-25.01) (AACCI, 2010). Digestible carbohydrates composed of available sugars and starch were analyzed by method 982.14 and total dietary fiber was quantified by method 978.10 (AOAC, 2019). All analyzes were performed in triplicate.

The total phenolic compounds content of the standard sample, the optimal point and the olive pomace flour was determined according to the methodology proposed by Cáceres, Martínez-Villaluenga, Amigo, \& Frias, (2014). Briefly, an aliquot of $1.5 \mathrm{~g}$ of the sample on a wet basis was weighed in a $50 \mathrm{~mL}$ falcon tube (in duplicate) using an AVY220 analytical balance (Shimadzu, Barra Funda, BRA). Then, $9 \mathrm{~mL}$ of methanol:water (60:40 v/v) solution was added. The tubes were coated 
with aluminum foil to avoid contact with light and kept under agitation on a shaker at $240 \mathrm{rpm}$ and room temperature $(20 \mathrm{C})$ for $16 \mathrm{~h}$. Then, the samples were centrifuged in a BL206 centrifuge (Fanem, Guarulhos, BRA) at $2500 \times \mathrm{g}$ for $10 \mathrm{~min}$. The supernatant was transferred to $10 \mathrm{~mL}$ volumetric flasks, and the volume was adjusted with the extractor solution and covered with aluminum foil. In triplicate, an aliquot of $100 \mu \mathrm{L}$ of each diluted extract was transferred to test tubes, added $250 \mu \mathrm{L}$ FolinCiocalteu $2 \mathrm{~N}$ phenol reagent, $3 \mathrm{~mL}$ of distilled water and $1 \mathrm{~mL}$ of $15 \%$ sodium carbonate solution $(\mathrm{m} / \mathrm{v})$. The test tubes were manually shaken and incubated in the dark at room temperature for $30 \mathrm{~min}$. The absorbance of the samples was measured in a UV-M5 1 spectrophotometer (Bel Photonics, Monza, ITA) with a wavelength of $750 \mathrm{~nm}$, using a standard 7-point of the gallic acid curve $(0$ to $150 \mathrm{mg} / \mathrm{L})\left(\mathrm{y}=0.002 \mathrm{x}-0.005 ; \mathrm{r}^{2}=0.9943\right)$. The results were expressed in $\mathrm{mg}$ of gallic acid per $100 \mathrm{~g}$ of sample (in wet basis).

The total caloric value was calculated considering the Atwater conversion method, as described by Souza and Schmiele (2021). For the total caloric value, conversion values of $4 \mathrm{kcal}^{-1} \mathrm{~g}^{-1}$ for proteins and digestible carbohydrates (sugars and starch) and $9 \mathrm{kcal}^{-\mathrm{g}^{-1}}$ for lipids were considered (Simanca-Sotelo et al., 2021).

\subsubsection{Image analysis of the alveoli of the slices}

The slices of bread were evaluated for their alveolar structure as described by Tasiguano, Villarreal, Schmiele, \& Vernaza (2019). The values of total area $\left(\mathrm{cm}^{2}\right)$, number of alveoli per slice, the average size of alveoli $\left(\mathrm{mm}^{2}\right)$, percentage of alveoli area (\%) and circularity were assessed with four repetitions. Images were obtained by scanning at 600 dpi resolution in an MFC-895DW scanner (Brother, Ho Chi Minh, VTN) using black background paper. Images were saved in Joint Photographic Experts Group (jpeg) format and analyzed using Image J software (National Institutes of Health, Bethesda, USA). The measurements from the images were obtained in pixels and converted to mm using length values based on the shape's width $(10 \mathrm{~cm})$. According to Silva et al. (2021), the data were obtained after tracing the outline of the rectangular section of the bread slices. For cell analysis, images were set to 8-bit grayscale format, the contrast was adjusted, and Otsu's algorithm was chosen for thresholding.

\subsection{Statistical analysis}

The data obtained to the trials from the Simplex-Centroid Mixture Design were evaluated using the Response Surface Methodology to calculate the regression coefficients and analysis of variance (ANOVA) with a significance level of $10 \%$ and a minimum regression coefficient $\left(\mathrm{R}^{2}\right)$ of 0.70 , according to the general model expressed by Equation 2 (Rodrigues \& Iemma, 2014).

$$
Y=\beta_{1} x_{1}+\beta_{2} x_{2}+\beta_{3} x_{3}+\beta_{12} x_{1} x_{2}+\beta_{13} x_{1} x_{3}+\beta_{23} x_{2} x_{2}+\beta_{123} x_{1} x_{2} x_{3}+\varepsilon
$$

Where: $\mathrm{Y}=$ value related to the dependent variable; $\beta_{\mathrm{i}}$ and $\beta_{\mathrm{ij}}=$ are the regression coefficients for the pseudocomponent and the binary and ternary components, respectively; $\varepsilon=$ is the error; $\mathrm{x}_{\mathrm{i}}$ and $\mathrm{x}_{\mathrm{j}}=$ is the coded value for the independent variables.

Data on instrumental color and proximate composition of raw materials (refined wheat flour, hydrogenated vegetable fat, sucrose, olive pomace flour, extra virgin olive oil and hydrolyzed soy protein) were evaluated by ANOVA and, when statistically significant differences were observed, the Tukey test was used to compare the means $(P<0.05)$. In addition, the chemical composition and image analysis of the alveoli of the slices data of the standard formulation and the optimized point were evaluated by the t-Student test $(P<0.05)$. 
The project is registered under number AA4D812 in the National System for the Management of Genetic Heritage and Associated Traditional Knowledge (SisGen) of the Ministry of the Environment of the Federative Republic of Brazil.

\section{Results and Discussion}

\subsection{Technological aspects of the batter}

\subsubsection{Specific gravimetry}

The specific gravity of the batter ranged between $0.35 \pm 0.01$ and $0.90 \pm 0.11 \mathrm{~g} . \mathrm{cm}^{-3}$ (Table 2). It was observed that the best effect was provided by the binary component between extra virgin olive oil and hydrolyzed soy protein $\left(\beta_{23}=-1.89\right.$; $P<0.001$ ), favoring the incorporation of air in the batter, reducing the values of this dependent variable. The ANOVA indicated that $98.02 \%$ of the responses obtained were explained by the mathematical model $\left(\mathrm{F}_{\text {calc }} / \mathrm{F}_{\text {tab }} 4 ; 7 ; 0.10=3.06, P=0.007\right)$. According to Figure 3, intermediate values $(20-30 \%)$ of hydrolyzed soy protein resulted in light and aerated batter. This effect can be attributed to the surfactant property of soy protein due to the balance between the polar (basic, acid and neutral) and hydrophobic amino acid profile, which are responsible for favoring emulsification and batter aeration. Among the basic amino acids, lysine and arginine stand out with approximate contents of 6.75 and $3.06 \%$, acids and neutrals such as glutamic acid and glutamine $(24.82 \%)$ and aspartic acid and asparagine $(11.65 \%)$. On the other hand, the hydrophobic amino acids that present the highest fraction in soy protein are leucine $(7.76 \%)$, proline $(6.24 \%)$, phenylalanine $(5.86 \%)$, valine $(4.39 \%)$, alanine $(4.35 \%)$ and isoleucine $(3.95 \%)$ (Chen et al., 2020).

Table 2 - Specific gravity $\left(\mathrm{g} . \mathrm{cm}^{-3}\right)$ and $\mathrm{pH}$ of the batters elaborated with olive pomace flour, soy protein hydrolysate and extra virgin olive oil for muffin production from the Simplex Centroid Mixture Design.

\begin{tabular}{ccc}
\hline Trials & Specific gravity $\left(\mathbf{g . c m}^{-\mathbf{3}}\right)$ & $\mathbf{p H}$ \\
\hline 1 & $0.79 \pm 0.01$ & $6.58 \pm 0.14$ \\
2 & $0.83 \pm 0.02$ & $6.29 \pm 0.05$ \\
3 & $0.90 \pm 0.11$ & $5.96 \pm 0.06$ \\
4 & $0.77 \pm 0.01$ & $6.21 \pm 0.10$ \\
5 & $0.75 \pm 0.04$ & $5.94 \pm 0.03$ \\
6 & $0.35 \pm 0.01$ & $6.01 \pm 0.02$ \\
7 & $0.77 \pm 0.01$ & $6.16 \pm 0.05$ \\
8 & $0.82 \pm 0.01$ & $5.84 \pm 0.13$ \\
9 & $0.81 \pm 0.01$ & $5.78 \pm 0.03$ \\
10 & $0.80 \pm 0.02$ & $6.04 \pm 0.02$ \\
11 & $0.73 \pm 0.06$ & $6.08 \pm 0.02$ \\
12 & $0.77 \pm 0.04$ & $6.11 \pm 0.01$ \\
Standard & $0.83 \pm 0.01$ & $6.11 \pm 0.01$ \\
\hline
\end{tabular}

Means of three repetitions \pm standard deviation. Source: Authors (2022).

\subsection{2 $\mathrm{pH}$ of batter}

The $\mathrm{pH}$ of the batter ranged between $5.78 \pm 0.03$ and $6.58 \pm 0.14$ (Table 2). It was observed that the olive pomace flour $\left(\beta_{1}=6.51 ; P<0.001\right)$ favored the increase in $\mathrm{pH}$ and the binary component between olive pomace flour and hydrolyzed soy protein $\left(\beta_{13}=-1.22 ; P=0.067\right)$ resulted in a decrease in $\mathrm{pH}$. The ANOVA indicated that $70.96 \%$ of the responses obtained were explained by the mathematical model $\left(\mathrm{F}_{\text {calc }} / \mathrm{F}_{\text {tab } 3 ; 8 ; 0.10}=2.23 ; P=0.015\right)$. According to Figure 3 , higher values $(40-50$ $\%)$ of olive pomace flour resulted in batter with $\mathrm{pH}$ values closer to neutrality (6.5) and higher values (30 - $50 \%)$ of 
hydrolyzed soy protein resulted in pasta with a lower $\mathrm{pH}$ (5.9). These effects can be attributed to the ability of the protein content of the hydrolyzed soy protein to release $\mathrm{H}^{+}$ions concerning the olive pomace flour that had a lower influence on the $\mathrm{pH}$ scale, the composition of the flour can explain the lower contribution in organic acids weak ones that have less dissociation of $\mathrm{H}^{+}$ions. A slight reduction of $\mathrm{pH}$ values in the muffin batter is attractive because the reaction triggered by the baking powder results in an increase in $\mathrm{pH}$. In alkaline media, the rate of $\mathrm{CO}_{2}$ release is reduced. In this way, independent variables favor the release of the gas responsible for the muffin growth during the baking step.

\subsection{Technological aspects of the muffin}

\subsection{1 $\mathrm{pH}$ and total titratable acidity}

The $\mathrm{pH}$ of the muffins was found between $6.29 \pm 0.02$ and $7.13 \pm 0.08$ (Table 3). It was observed that extra virgin olive oil $\left(\beta^{2}=7.12 ; P<0.001\right)$ favored higher $\mathrm{pH}$ values and the binary component between extra virgin olive oil and hydrolyzed soy protein $\left(\beta_{23}=-0.89 ; P=0.002\right)$ contributed to the reduction of this response. The ANOVA indicated that the mathematical model explained $98.02 \%$ of the responses obtained $\left(\mathrm{F}_{\text {calc }} / \mathrm{F}_{\text {tab }} 47 ; 0.10=29.27 ; P<0.001\right)$. As shown in Figure 3 , higher levels of hydrolyzed soy protein (35-50\%) resulted in lower $\mathrm{pH}$ values and higher levels of extra virgin olive oil (20$25 \%$ ) resulted in increased $\mathrm{pH}$. These effects can be attributed to the ability of the peptides and amino acids present in the hydrolyzed soy protein to release $\mathrm{H}^{+}$ions and provide a greater contribution to reducing the $\mathrm{pH}$ of muffins concerning extra virgin olive oil, which had a lower influence on the scale of $\mathrm{pH}$. In addition to free fatty acids, extra virgin olive oil has a high content of phenolic compounds, especially those derived from hydroxybenzoic acids (vanillic acid) and hydroxycinnamic acids ( $p$-coumaric and ferulic acids) (Wang et al., 2021) due to their chemical composition in weak organic acids, which shown lower dissociation of $\mathrm{H}^{+}$ions. During the baking of the muffins, depending on the heat applied, the formation of conjugated or bound phenolic compounds may occur, reducing the ionization of phenolic acids. This same effect may have occurred with the phenolic acids present in the olive pomace flour during dehydration.

Table $3-\mathrm{pH}$ and total titratable acidity of muffins elaborated with olive pomace flour, soy protein hydrolysate and extra virgin olive oil for muffin production from the Simplex Centroid Mixture Design.

\begin{tabular}{ccc}
\hline Trials & $\mathbf{p H}$ & Total titratable acidity $(\mathbf{m g} \mathbf{~ K O H . g} \mathbf{1}$ sample in wb) \\
\hline 1 & $6.77 \pm 0.03$ & $0.65 \pm 0.03$ \\
2 & $7.13 \pm 0.08$ & $0.28 \pm 0.04$ \\
3 & $6.31 \pm 0.01$ & $2.09 \pm 0.04$ \\
4 & $6.87 \pm 0.05$ & $0.57 \pm 0.04$ \\
5 & $6.44 \pm 0.04$ & $1.49 \pm 0.03$ \\
6 & $6.52 \pm 0.03$ & $1.18 \pm 0.03$ \\
7 & $6.64 \pm 0.02$ & $0.88 \pm 0.03$ \\
8 & $6.84 \pm 0.02$ & $0.57 \pm 0.03$ \\
9 & $6.29 \pm 0.02$ & $1.55 \pm 0.04$ \\
10 & $6.55 \pm 0.02$ & $1.00 \pm 0.04$ \\
11 & $6.57 \pm 0.02$ & $1.02 \pm 0.03$ \\
12 & $6.57 \pm 0.02$ & $1.02 \pm 0.04$ \\
Standard & $7.27 \pm 0.04$ & $0.33 \pm 0.04$ \\
\hline
\end{tabular}

Means of three repetitions \pm standard deviation. Source: Authors (2022). 
As shown in Table 3, the total titratable acidity of the muffins ranged between $0.28 \pm 0.04$ and $2.09 \pm 0.04 \mathrm{mg}$ of $\mathrm{KOH} . \mathrm{g}^{-1}$ of sample (wb). It was observed that the ternary component of olive pomace flour, extra virgin olive oil and hydrolyzed soy protein $\left(\beta_{123}=-2.65 ; P=0.013\right)$ favored the reduction of titratable total acidity values and hydrolyzed soy protein $\left(\beta_{3}=2.09 ; P<0.001\right)$ provided higher values of the dependent variable. The ANOVA indicated that the mathematical model explained $99.77 \%$ of the responses obtained $\left(\mathrm{F}_{\text {calc }} / \mathrm{F}_{\text {tab 5;6;0.10 }}=170.60 ; P<0.001\right)$. According to Figure 3, higher values of hydrolyzed soy protein $(30-50 \%)$ resulted in higher acidity values, and higher values of extra virgin olive oil $(20-25 \%)$ resulted in lower acidity values. These effects can be attributed to the buffering character of the amino acids present in the hydrolyzed soy protein, which interferes in the analysis of titratable acidity in a way that overestimates the results. The condensation of the phenolic acids reported in the $\mathrm{pH}$ of the cakes confirms this result.

Figure 3 - Contour plots for specific gravity and $\mathrm{pH}$ of batter and $\mathrm{pH}$ and total titratable acidity of muffins within the trials from the Simplex Centroid Mixture Design.

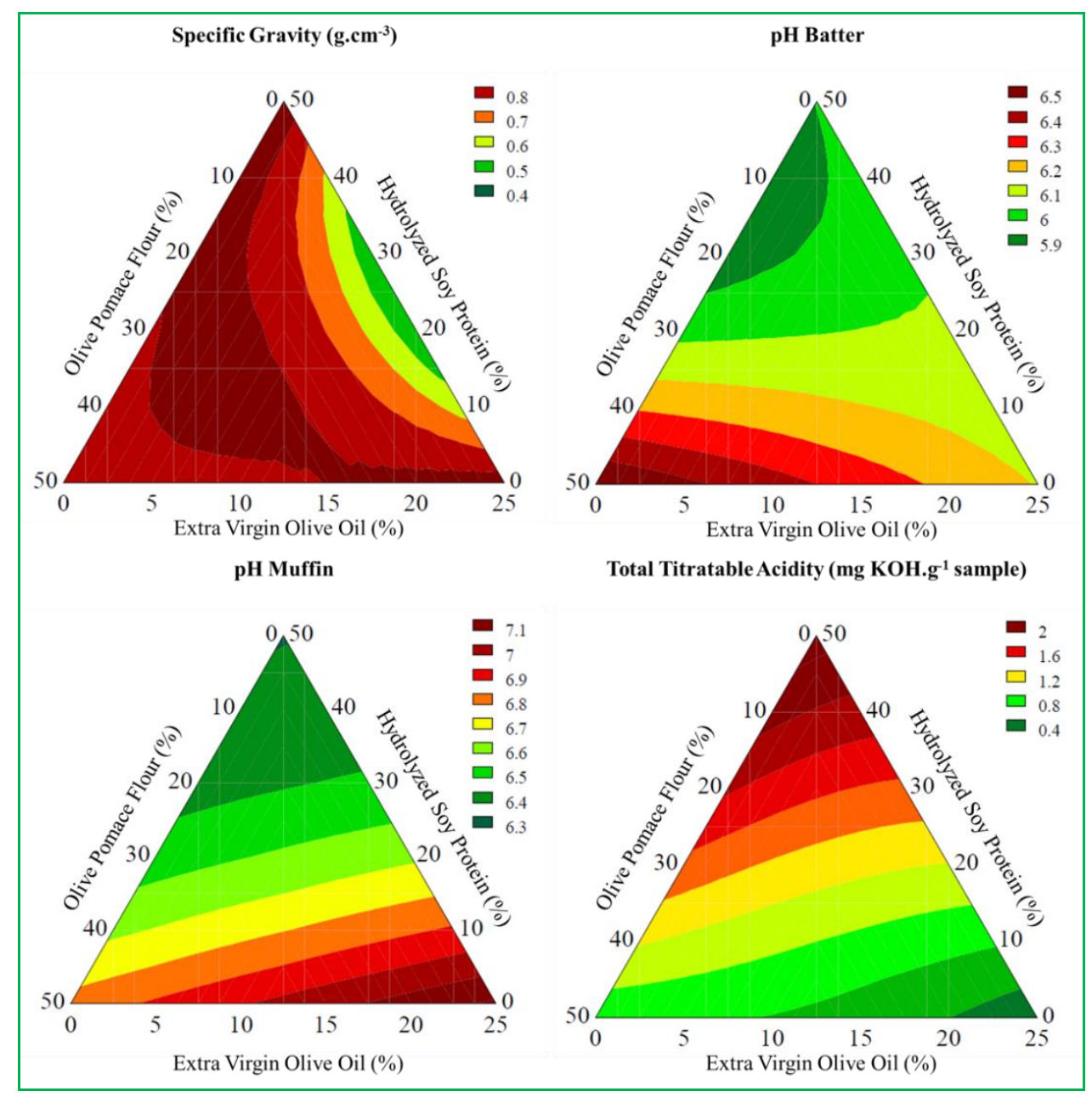

Source: Authors (2022).

\subsubsection{Water activity}

Water activity represents the fraction of free water available for deterioration reactions, being used as an indicator of conservation. The results for water activity (Table 4) of the muffins ranged between $0.8713 \pm 0.0229$ and $0.9217 \pm 0.0130$. It was observed that the pseudo components had a significant influence $(P<0.001)$ on the water activity of the muffins, with regression coefficients of 0.8627 for olive pomace flour, 0.8767 for extra virgin olive oil and 0.9169 for hydrolyzed soy protein. However, the ANOVA data indicate that the mathematical model was not predictive as it explained less than $70 \%$ of 
the experimental data. The standard sample showed a water activity of $0.9066 \pm 0.0138$ and the average of the tests was 0.8972. In general, this result indicated that the ingredients substituted in the muffin formulation are viable and promote minimal variations in the free water content of the samples.

Table 4 - Water activity and specific volume of muffins elaborated with olive pomace flour, soy protein hydrolysate and extra virgin olive oil for muffin production from the Simplex Centroid Mixture Design.

\begin{tabular}{ccc}
\hline Trials & Water activity & Specific volume $\left(\mathbf{c m}^{3} / \mathbf{g}\right)$ \\
\hline 1 & $0.8713 \pm 0.0229$ & $2.17 \pm 0.02$ \\
2 & $0.8718 \pm 0.0316$ & $2.42 \pm 0.03$ \\
3 & $0.9174 \pm 0.0252$ & $2.09 \pm 0.06$ \\
4 & $0.8863 \pm 0.0236$ & $2.34 \pm 0.16$ \\
5 & $0.9217 \pm 0.0130$ & $2.23 \pm 0.11$ \\
6 & $0.9215 \pm 0.0054$ & $2.21 \pm 0.13$ \\
7 & $0.8549 \pm 0.0373$ & $2.25 \pm 0.11$ \\
8 & $0.9043 \pm 0.0161$ & $2.22 \pm 0.05$ \\
9 & $0.9117 \pm 0.0106$ & $2.10 \pm 0.07$ \\
10 & $0.8894 \pm 0.0171$ & $2.21 \pm 0.09$ \\
11 & $0.9042 \pm 0.0112$ & $2.23 \pm 0.11$ \\
12 & $0.9124 \pm 0.0077$ & $2.35 \pm 0.17$ \\
\hline
\end{tabular}

Means of three repetitions \pm standard deviation. Source: Authors (2022).

\subsubsection{Specific volume}

The specific volume is associated with the increase in the volume of cakes resulting from the chemical reaction of $\mathrm{CO}_{2}$ release and the expansion of gases during baking. The results varied between $2.09 \pm 0.06$ and $2.42 \pm 0.03 \mathrm{~cm}^{3} \cdot \mathrm{g}^{-1}$ for the assays and were $2.40 \pm 0.08 \mathrm{~cm}^{3} \cdot \mathrm{g}^{-1}$ for the standard sample (Table 4). The results showed no statistically significant difference $(P>0.10)$ because the mathematical model does not predict the minimum percentage of results stipulated for this study (70 $\%)$. The substitutions of some ingredients in the muffin formulation and the similar behavior indicate that the specific volume was homogeneous for all samples. However, it was observed that the pseudo components had a positive effect $(P<0.001)$ on the development of the specific volume of the muffins, with the best impact provided by extra virgin olive oil, followed by olive pomace flour and hydrolyzed soy protein, with regression coefficients of 2.40, 2.17 and 2.08, respectively. The specific volume results from the homogeneous incorporation of air into the batter, with uniform distribution. The air bubbles trapped in the batter are critical in allowing the $\mathrm{CO}_{2}$ released by the baking powder to promote product expansion during baking, as $\mathrm{CO}_{2}$ itself cannot create gas bubbles (Souza \& Schmiele, 2021).

\subsubsection{Instrumental color}

The results obtained in the analysis of the instrumental color for the parameters $L^{*}, a^{*}, b^{*}$ and color difference $(\Delta \mathrm{E})$ are presented in Table 5. The values of luminosity $\left(L^{*}\right)$ of the trials ranged between $37.80 \pm 2.28$ and $78.04 \pm 0.33$, with 99.58 $\%$ of the results being explained by the mathematical model, according to ANOVA $\left(\mathrm{F}_{\text {calc }} / \mathrm{F}_{\text {tab } 4 ; 5 ; 0.10}=141.36, P<0.001\right)$. The binary interactions between olive pomace flour and extra virgin olive oil $\left(\beta_{12}=-37.29 ; P<0.001\right)$ and extra virgin olive oil and hydrolyzed soy protein $\left(\beta_{23}=-15.88 ; P=0.003\right)$ showed negative effects on the luminosity of the samples, resulting in products with darker ton than the standard formulation. On the other hand, using the pseudo components alone in the muffins had positive effects on the luminosity of the samples, with extra virgin olive oil being the ingredient with the most significant 
impact on this parameter $\left(\beta_{2}=77.41 ; P<0.001\right)$. In this sense, it is inferred that the olive pomace flour and hydrolyzed soy protein in the binary components are responsible for the darkening of the samples in these cases, overlapping the effect provided by the extra virgin olive oil. Especially olive pomace flour has a marked effect on this parameter. Indeed, this is a low light ingredient $\left(L^{*}=37.42 \pm 0.93\right)$ (Table 6 ). As shown by the contour curve of the $L^{*}$ parameter in (Figure 4 ), olive pomace flour resulted in darker muffins when compared to the presence of hydrolyzed soy protein.

Table 5 - Instrumental color of muffins elaborated with olive pomace flour, soy protein hydrolysate and extra virgin olive oil for muffin production from the Simplex Centroid Mixture Design.

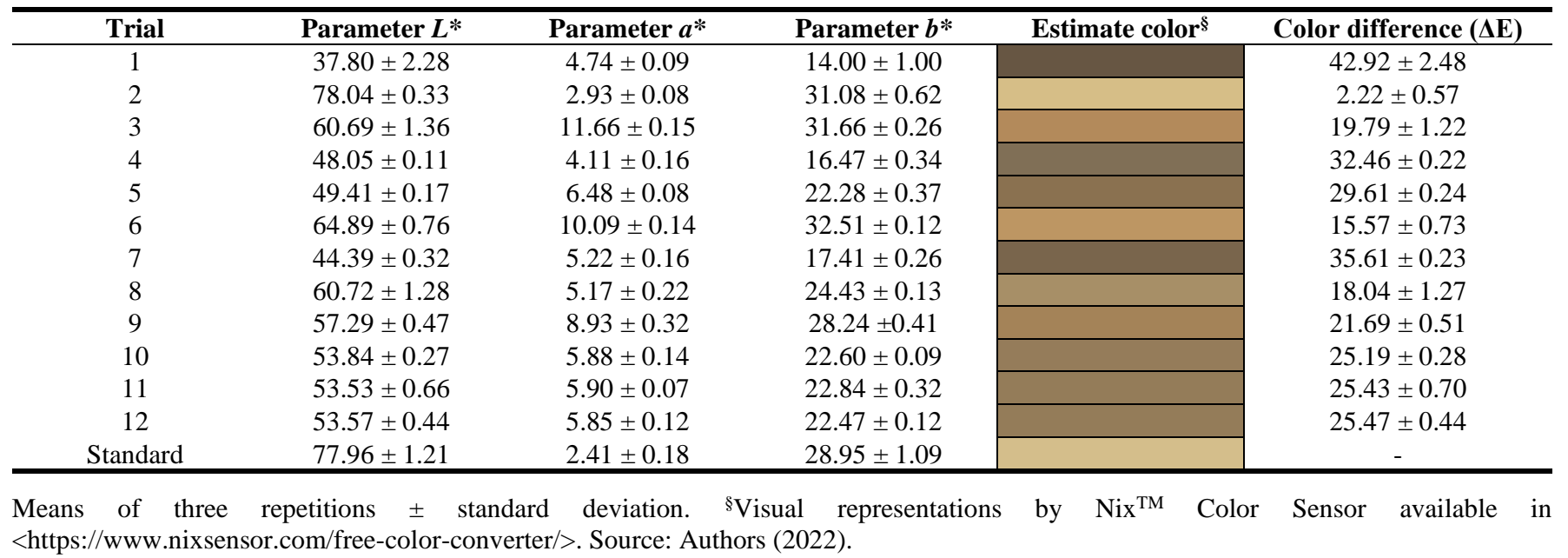

Maillard reaction occurs through the condensation of a carbonyl compound (such as reducing sugar) with a nonprotonated amine (from an amino acid), leading to the formation of brown or black pigments of high molecular weight (Damodaran \& Parkin, 2019). Thus, it is expected that the luminosity would decrease and the parameters $a^{*}$ and $b^{*}$ would approach reddish/yellowish tones, regardless of the addition of the substituting ingredients.

The parameter $a^{*}$ of instrumental color presented values between $2.41 \pm 0.18$ and $11.66 \pm 0.15$. According to ANOVA, $99.55 \%$ of the results can be explained by the mathematical model $\left(\mathrm{F}_{\text {calc }} / \mathrm{F}_{\text {tab }} ; ; ; 0 ; 0.10=85.12, P<0.001\right)$. The binary component between olive pomace flour and hydrolyzed soy protein $\left(\beta_{13}=-6.90 ; P<0.001\right)$ and the ternary components $\left(\beta_{123}\right.$ $=-27.92 ; P=0.002)$ promotes a decrease in the parameter, bringing the muffin color closer to the green hue. Indeed, olive pomace flour has a greenish color as a function of chlorophyll, resulting from the integral use of olives to produce flour (peel, pulp and seed) (Silva, 2020), as shown in Table 6. Similarly, the extra virgin olive oil has a greenish hue from the chlorophyll $\left(a^{*}=2.34 \pm 0.07\right.$ ). Pheophytin $a$ and $b$ are the main chlorophyll pigments found in olive products, followed by chlorophyll $a$ and $b$, OH-pheophytin $a$ and $b$ and lactone-pheophytin $a$ and $b$ (Aparicio-Ruiz \& Gandul-Rojas, 2014). The influence of the coloring of the ingredients from the olive indicates that the initial structure of the pigment was maintained during the process of extracting extra virgin olive oil and drying the olive pomace (Al-Bachir, 2017; Scherer \& Böckel, 2018). In addition, it indicates the conservation of part of the chlorophyll in the muffin after the baking step, giving the final product a characteristic color.

The binary component between extra virgin olive oil and hydrolyzed soy protein and the use of the pseudo components increased the $a^{*}$ parameter (Table 5), bringing the color of the samples closer to the red ton, indicating a reddish hue to the crumb of the muffins. This result suggests that the green hue of extra virgin olive oil can be overlapped by the reddish hue of the hydrolyzed soy protein (in the range of $18-50 \%$ ), as can be seen in the contour curve of the $a^{*}$ parameter in Figure 4. 
Table 6. Color parameters estimated color and real appearance of raw materials used in the experimental design.

\begin{tabular}{|c|c|c|c|c|c|}
\hline \multirow{2}{*}{ Ingredients } & \multicolumn{5}{|c|}{ Parameters } \\
\hline & $L^{*}$ & $a^{*}$ & $b^{*}$ & Estimate color $^{\S}$ & Real appearance \\
\hline $\begin{array}{l}\text { Olive pomace } \\
\text { flour }\end{array}$ & $37.42 \pm 0.93^{\mathrm{e}}$ & $4.18 \pm 0.15^{b}$ & $12.15 \pm 0.69^{b}$ & & \\
\hline $\begin{array}{l}\text { Extra virgin } \\
\text { olive oil }\end{array}$ & $4.02 \pm 0.15^{\mathrm{f}}$ & $2.34 \pm 0.07^{\mathrm{c}}$ & $3.83 \pm 0.02^{\mathrm{d}}$ & & \\
\hline $\begin{array}{l}\text { Hydrolyzed soy } \\
\text { protein }\end{array}$ & $72.57 \pm 0.34^{\mathrm{d}}$ & $9.49 \pm 0.34^{\mathrm{a}}$ & $32.91 \pm 1.30^{\mathrm{a}}$ & & \\
\hline $\begin{array}{l}\text { Refined wheat } \\
\text { flour }\end{array}$ & $88.97 \pm 0.09^{b}$ & $0.36 \pm 0.00^{\mathrm{d}}$ & $11.16 \pm 0.05^{b c}$ & & \\
\hline $\begin{array}{l}\text { Hydrogenated } \\
\text { vegetable fat }\end{array}$ & $86.38 \pm 0.24^{\mathrm{c}}$ & $-3.93 \pm 0.01^{\mathrm{f}}$ & $9.55 \pm 0.06^{c}$ & & \\
\hline Sucrose & $92.21 \pm 0.14^{\mathrm{a}}$ & $-0.20 \pm 0.01^{\mathrm{e}}$ & $10.03 \pm 0.27^{\mathrm{c}}$ & & \\
\hline
\end{tabular}

Means of three repetitions \pm standard deviation. Different lowercase letters superscript in the column indicates a significant difference between temperatures by Tukey's test $(P<0.05)$. ${ }^{\S}$ Visual representations by Nix ${ }^{\mathrm{TM}}$ Color Sensor available in <https://www.nixsensor.com/free-color-converter/>. Source: Authors (2022).

The parameter $b^{*}$ ranged between $14.00 \pm 1.00$ and $32.51 \pm 0.12$, indicating the proximity of the muffins with a yellowish hue. According to ANOVA, $99.21 \%$ of the results are explained by the mathematical model $\left(\mathrm{F}_{\text {calc }} / \mathrm{F}_{\text {tab } 3 ; 8 ; 0.10}=\right.$ 114.79; $P<0.001)$. The binary component between olive pomace flour and extra virgin olive oil has a negative effect on the color of muffins $\left(\beta_{12}=-25.80 ; P<0.001\right)$ since it tends to bring $b^{*}$ closer to a grayish hue. On the other hand, the pseudo components applied alone result in better values on the color of the muffins, where the hydrolyzed soy protein has the greatest 
effect of approaching the $b^{*}$ parameter to the yellowish color $\left(\beta_{3}=31.82 ; P<0.001\right)$. This result is corroborated by the contour curve of the parameter $b^{*}$ in Figure 4, where it was observed that the presence of hydrolyzed soy protein gives a more intense yellow hue to the muffins. Hydrolyzed soy protein has the highest $b^{*}$ parameter among the ingredients $\left(b^{*}=32.91 \pm 1.30\right)$ (Table 6). In addition, higher levels of extra virgin olive oil also intensify the yellowing. Lutein and $\beta$-carotene are the main carotenoids present in olive products. It is also known that other xanthophylls such as neoxanthin, violaxanthin, antheraxanthin and $\beta$-cryptoxanthin are present (Aparicio-Ruiz \& Gandul-Rojas, 2014; Arrizabalaga-Larrañaga et al., 2021). The presence of chlorophyll in extra virgin olive oil attenuates the intensity of these pigments. This effect can be seen in the images of trials $6>$ $3>2>9$ in Figure 5, which contain the highest amounts of these independent variables. This result corroborates the ability of hydrolyzed soy protein to bring the muffin tone closer to warmer colors (yellow and red), unlike the other ingredients (olive pomace flour and extra virgin olive oil), which tend to approximate the tone to cooler colors (blue and green).

Figure 4 - Contour plots for muffin's color properties within the trials from the Simplex-Centroid Mixture Design.

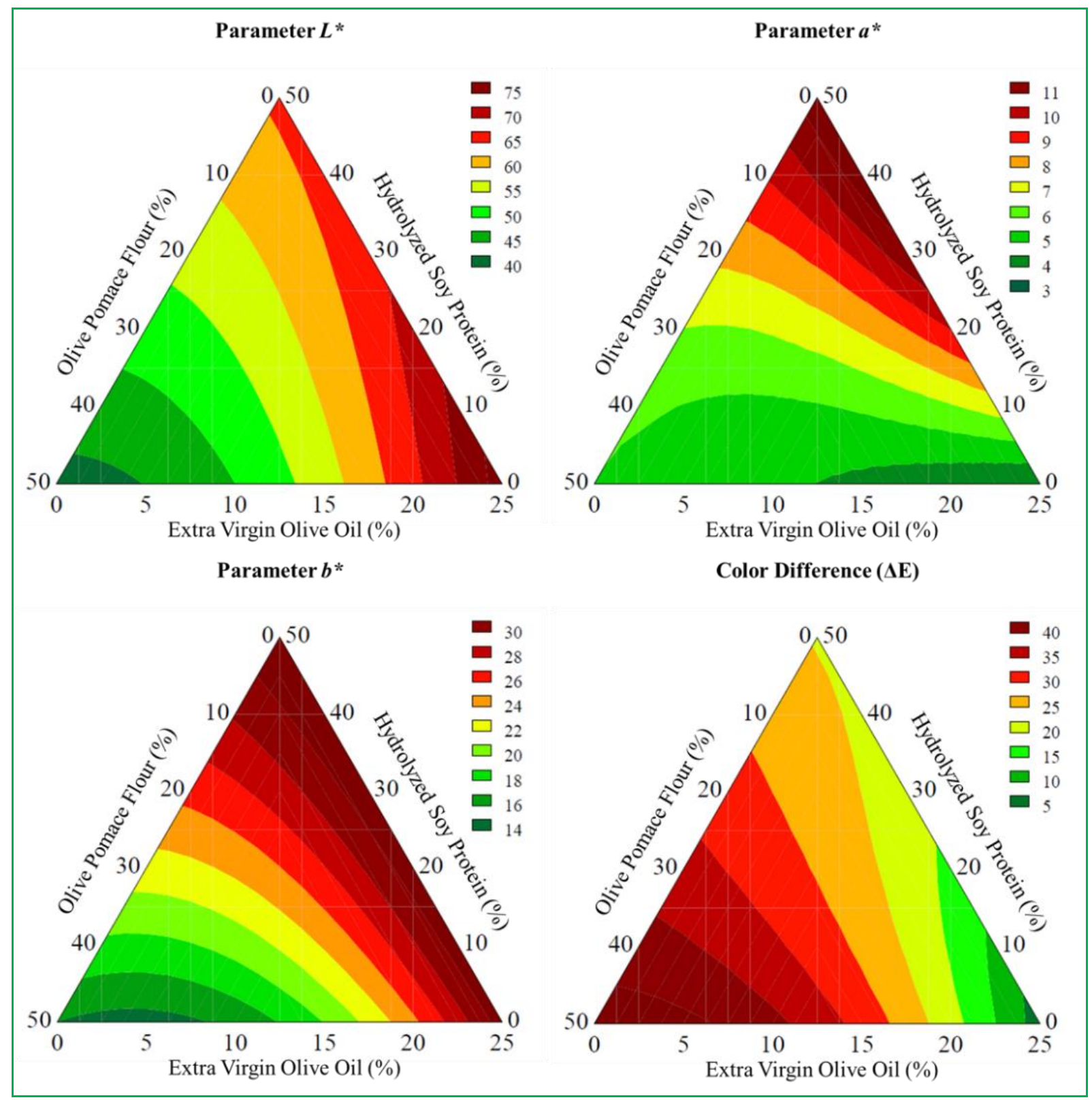

Source: Authors (2022). 
Martínez-Cervera et al. (2012) noted in their report on the rheological, sensory and texture characteristics of reformulated low-sugar muffins with high substitution of sucrose by polydextrose and sucralose presented crumbs with values of $a^{*}$ and $b^{*}$ more significant than the standard sample, bringing the muffin color closer to red/yellow. For the crusts, the parameters $L^{*}$ and $a^{*}$ did not differ, while the parameter $b^{*}$ showed a difference between the samples and the standard. As expected, the color of the crust was significantly darker than that of the crumb, a result of Maillard reactions during baking.

Figure 5 - Muffin's slices from the trials from the Simplex-Centroid Mixture Design.

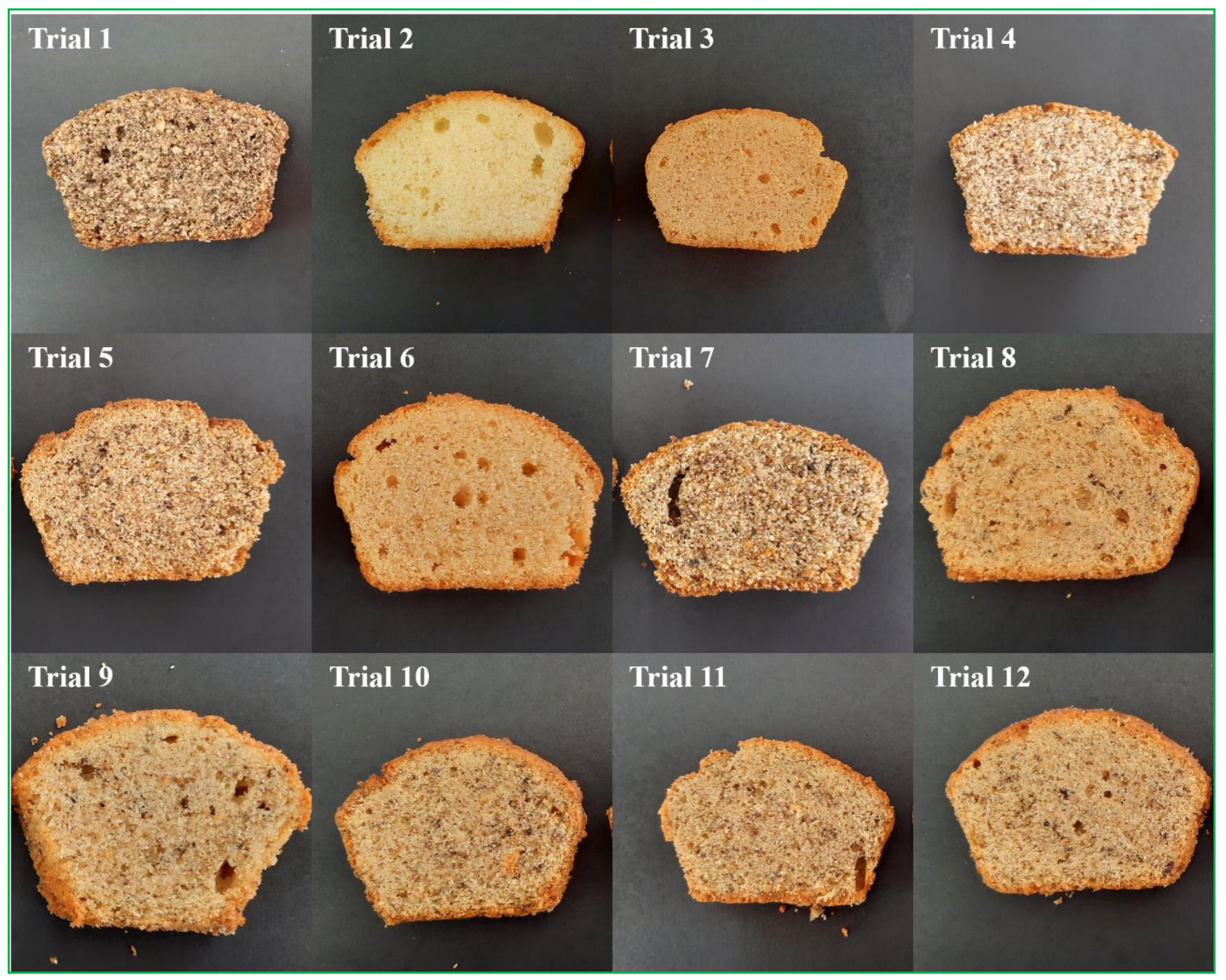

Source: Authors (2022).

In their study on the quality of muffins enriched with sunflower seed flour, Grasso, Liu, \& Methven (2020) found that muffins with the alternative flour had significantly different colors from the control sample, both by the instrumental color test and by the sensory analysis performed with untrained tasters. However, the overall acceptance and sensory quality of the enriched products (with up to $15 \%$ sunflower seed flour) was similar to the acceptance of the standard sample. In this way, the alternative flour would have the potential to be used in muffins, even with the darkening of the final product.

The color difference $(\Delta \mathrm{E})$ between the standard sample and the trials varied between $2.22 \pm 0.57$ and $42.92 \pm 2.48$. The ANOVA indicated that the mathematical model could explain $99.93 \%$ of the results obtained $\left(\mathrm{F}_{\text {calc }} / \mathrm{F}_{\text {tab } 6 ; 5 ; 0.10}=378.66\right.$; $P<0.001)$. According to the regression coefficients, the binary interaction between olive pomace flour and hydrolyzed soy protein $\left(\beta_{13}=-7.24 ; P=0.013\right)$, and the ternary combination between the components $\left(\beta_{123}=-51.74 ; P=0.004\right)$ have the 
effect of decreasing the absolute color difference between the muffin with ingredient substitution and the standard sample. According to the $\Delta \mathrm{E}$ contour curve in Figure 4, higher amounts of olive pomace flour (> 20\%) and hydrolyzed soy protein (> $20 \%$ ) cause extreme changes in the color of the muffins when compared to the standard. On the other hand, extra virgin olive oil attenuated the intensities of the muffins' color tones in small amounts (>20\%), having a significant effect at higher concentrations. The influence of extra virgin olive oil tends to be suppressed in the cases of the three-color parameters analyzed in the presence of the other components. The main effect is increasing the luminosity of the formulations where it was used as the only substituent. Indeed, the absolute difference in color between the standard and trial 2 (where only extra virgin olive oil was used) was the lowest observed in the experiment, as shown in Table 5 and the image of trial 2 in Figure 5. Mokrzycki e Tatol (2011) mention that $0<\Delta \mathrm{E}<1$ (observer does not notice the difference), $1<\Delta \mathrm{E}<2$ (only experienced observer can notice the difference) $2<\Delta \mathrm{E}<3.5$ (unexperienced observer also notices the difference), $3.5<\Delta \mathrm{E}<5$ (clear difference in color is noticed), and $5<\Delta \mathrm{E}$ (observe notices two different colors). In this way, it was evident that the substitution of ingredients in the formulation resulted in a color change that any consumer could observe. However, this does not indicate an unsatisfactory result. According to Table 5, the coloring of the ingredients used in the muffins has $L^{*}, a^{*}$ and $b^{*}$ parameters characteristic of the raw material.

\subsubsection{Texture profile analysis}

As described by Teotônio et al. (2021), texture and specific volume of bakery products are the most important parameters from the point of view of consumers. Measures of firmness, hardness, elasticity, cohesiveness, gumminess, chewiness and resilience are shown in Table 7.

Table 7 - Instrumental color of muffins elaborated with olive pomace flour, soy protein hydrolysate and extra virgin olive oil for muffin production from the Simplex Centroid Mixture Design.

\begin{tabular}{cccccccc}
\hline Trials & $\begin{array}{c}\text { Firmness } \\
(\mathbf{N})\end{array}$ & $\begin{array}{c}\text { Hardness } \\
(\mathbf{N})\end{array}$ & $\begin{array}{c}\text { Springiness } \\
(\boldsymbol{\%})\end{array}$ & $\begin{array}{c}\text { Cohesiveness } \\
(\boldsymbol{\%})\end{array}$ & $\begin{array}{c}\text { Gumminess } \\
(\mathbf{N})\end{array}$ & $\begin{array}{c}\text { Chewiness } \\
(\mathbf{N})\end{array}$ & \begin{tabular}{c} 
Resilience $(\%)$ \\
\hline 1
\end{tabular} \\
$12.14 \pm 0.67$ & $21.37 \pm 2.16$ & $66.15 \pm 1.81$ & $27.42 \pm 0.94$ & $5.86 \pm 0.71$ & $3.89 \pm 0.47$ & $9.06 \pm 0.29$ \\
2 & $14.05 \pm 1.49$ & $23.73 \pm 2.50$ & $76.62 \pm 0.93$ & $34.54 \pm 1.85$ & $7.95 \pm 0.73$ & $6.09 \pm 0.58$ & $11.35 \pm 0.65$ \\
3 & $27.14 \pm 3.51$ & $41.96 \pm 5.84$ & $64.12 \pm 2.50$ & $23.78 \pm 1.51$ & $10.40 \pm 1.26$ & $6.56 \pm 0.87$ & $7.88 \pm 0.51$ \\
4 & $10.23 \pm 0.94$ & $17.93 \pm 1.16$ & $72.53 \pm 1.78$ & $31.29 \pm 1.65$ & $5.53 \pm 0.47$ & $4.00 \pm 0.35$ & $10.54 \pm 0.57$ \\
5 & $13.97 \pm 1.11$ & $24.56 \pm 2.54$ & $63.87 \pm 1.06$ & $25.61 \pm 1.11$ & $6.28 \pm 0.74$ & $4.02 \pm 0.51$ & $8.41 \pm 0.37$ \\
6 & $17.89 \pm 1.55$ & $27.79 \pm 1.96$ & $71.61 \pm 2.28$ & $28.91 \pm 1.49$ & $7.95 \pm 0.76$ & $5.47 \pm 0.36$ & $9.19 \pm 0.43$ \\
7 & $14.89 \pm 1.09$ & $22.19 \pm 2.50$ & $72.44 \pm 1.84$ & $27.50 \pm 1.53$ & $5.73 \pm 0.67$ & $4.10 \pm 0.46$ & $9.22 \pm 0.57$ \\
8 & $14.29 \pm 0.71$ & $22.97 \pm 2.19$ & $75.30 \pm 2.14$ & $32.55 \pm 1.17$ & $7.49 \pm 0.76$ & $6.22 \pm 0.50$ & $10.64 \pm 0.45$ \\
9 & $25.08 \pm 3.26$ & $37.39 \pm 5.96$ & $68.00 \pm 2.32$ & $25.04 \pm 1.06$ & $9.70 \pm 1.25$ & $6.62 \pm 0.81$ & $8.28 \pm 0.35$ \\
10 & $12.65 \pm 0.88$ & $21.08 \pm 2.51$ & $70.43 \pm 2.18$ & $28.21 \pm 1.47$ & $6.28 \pm 0.58$ & $4.43 \pm 0.38$ & $9.27 \pm 0.46$ \\
11 & $12.77 \pm 0.97$ & $22.43 \pm 1.61$ & $72.31 \pm 1.86$ & $29.50 \pm 1.33$ & $6.69 \pm 0.57$ & $4.83 \pm 0.47$ & $9.71 \pm 0.42$ \\
12 & $12.66 \pm 1.94$ & $21.16 \pm 3.66$ & $72.15 \pm 2.12$ & $29.47 \pm 2.07$ & $6.55 \pm 1.09$ & $4.50 \pm 0.68$ & $9.69 \pm 0.71$ \\
Standard & $15.10 \pm 2.23$ & $23.00 \pm 2.17$ & $75.44 \pm 1.60$ & $33.13 \pm 1.87$ & $7.87 \pm 0.99$ & $6.00 \pm 0.63$ & $10.49 \pm 0.75$ \\
\hline
\end{tabular}

Means of ten repetitions \pm standard deviation. Source: Authors (2022).

The crumb firmness ranged between $12.14 \pm 0.67$ and $27.14 \pm 3.51 \mathrm{~N}$, with the best effect provided by the binary component of olive pomace flour and hydrolyzed soy protein $\left(\beta_{13}=-20.06 ; \mathrm{p}=0.100\right)$, providing a muffin with a smooth crumb texture. According to ANOVA, $80.90 \%$ of the data could be explained by the mathematical model $\left(\mathrm{F}_{\text {calc }} / \mathrm{F}_{\text {tab }} 3 ; 8 ; 0.10=\right.$ $3.87, P=0.003)$. Crumb hardness varied between $17.93 \pm 1.16$ and $41.96 \pm 5.84 \mathrm{~N}$, and the best results were obtained with the 
binary combination of olive pomace flour and hydrolyzed soy protein $\left(\beta_{13}=-26.81 ; P=0.098\right)$. ANOVA showed that $83.99 \%$ of the results are adjusted by the mathematical model obtained from the regression coefficients $\left(\mathrm{F}_{\text {calc }} / \mathrm{F}_{\text {tab } 3 ; 8 ; 0.10}=4.79 ; P=\right.$ 0.002). Firmness and hardness complement each other, being directly proportional to the specific gravity of the batter and inversely proportional to the specific volume of the cakes (Souza \& Schmiele, 2021). In these cases, olive pomace flour appears as an important factor for the softness of the cakes after baking, helping to reduce the force required for deformation and cake rupture due to more aerated batter and uniform alveolar structures. Furthermore, the contour curves for firmness and hardness (Figure 6) show very similar patterns of behavior, where smaller amounts of extra virgin olive oil are responsible for providing lower values of firmness (range between $0-10 \%$ ) and hardness (range between $0-5 \%$ ). Furthermore, it was observed that the higher the content of hydrolyzed soybean protein, the higher the values for these parameters.

Figure 6 - Contour plots for muffin's firmness, hardness, springiness and cohesiveness within the trials from the SimplexCentroid Mixture Design.

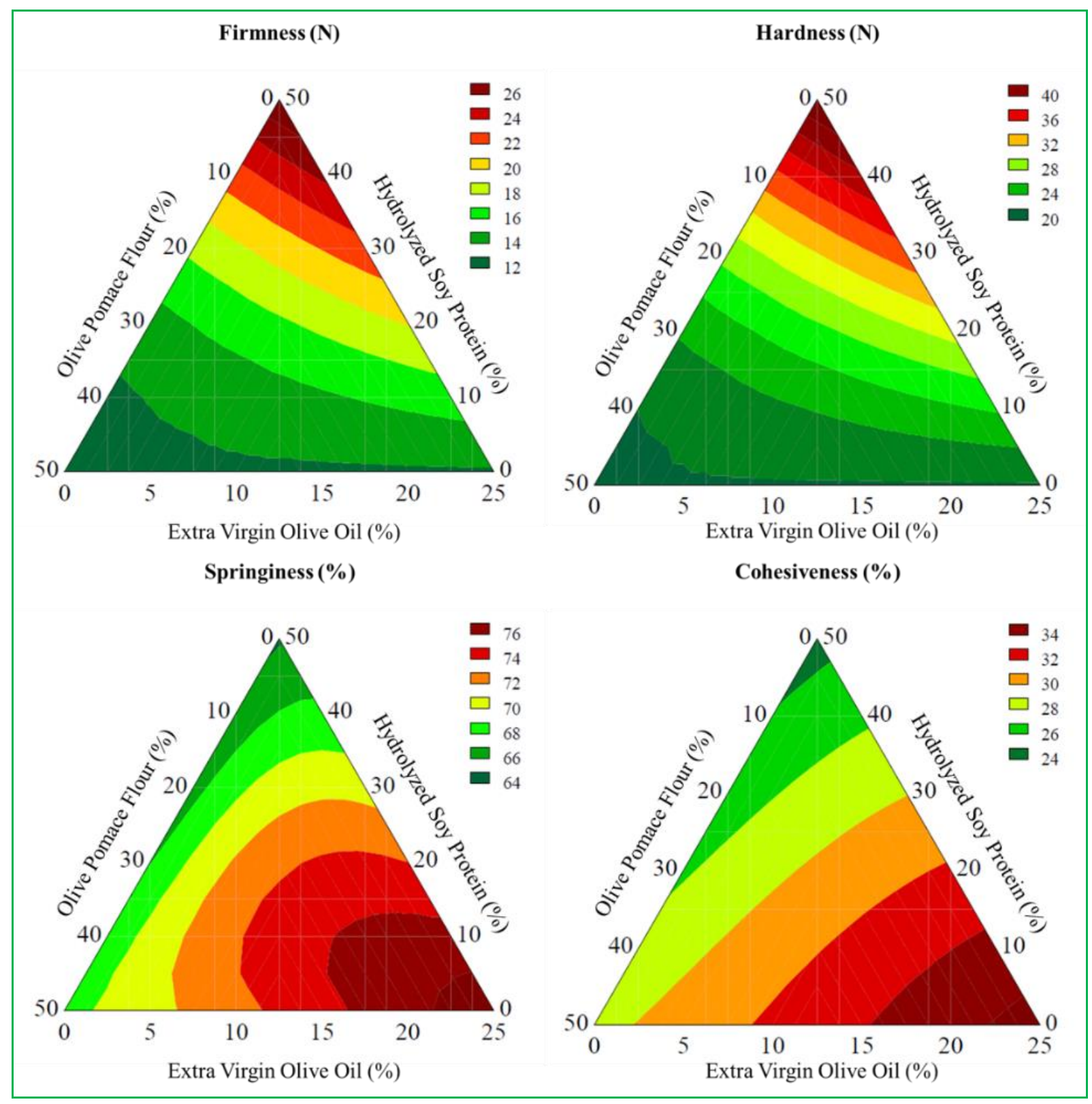

Source: Authors (2022). 
The elasticity of the muffins crumb ranged from $63.87 \pm 1.06$ to $76.62 \pm 0.93 \%$, and $91.40 \%$ of the results were explained by the mathematical model $\left(\mathrm{F}_{\text {calc }} / \mathrm{F}_{\text {tab } 3 ; 8 ; 0.10}=9.71 ; P<0.001\right)$ according to ANOVA. The model obtained indicated that the individual application of the independent variables $\left(\beta_{1}=67.33 ; P<0.001, \beta_{2}=77.44 ; P<0.001, \beta_{3}=63.79 ; P<\right.$ $0.001)$ and the ternary component result in an increase in the elasticity of the crumb $\left(\beta_{123}=71.47 ; P=0.026\right)$, with extra virgin olive oil being the main responsible for this effect. Similar behavior is observed in the cohesiveness parameter. This property ranged from $23.78 \pm 1.51$ to $34.54 \pm 1.85 \%$, with $96.65 \%$ of the results being explained by the mathematical model, according to ANOVA $\left(\mathrm{F}_{\mathrm{calc}} / \mathrm{F}_{\text {tab }} 3 ; 8 ; 0.10=26.37 ; P<0.001\right)$. In this case, only the individual application of the pseudocomponents showed a significant effect on the cohesiveness of the muffin, where extra virgin olive oil was responsible for a greater influence $\left(\beta_{2}=34.87 ; P<0.001\right)$. In this sense, these parameters present complementary results, presenting extra virgin olive oil as the ingredient with the greatest influence. It can be seen from the elasticity and cohesiveness contour plots (Figure 6) that higher levels of extra virgin olive oil $\left(\mathrm{x}_{2}=16-25 \% ; \mathrm{x}_{2}=15-25 \%\right)$ and of olive pomace flour $\left(\mathrm{x}_{1}>30 \%\right.$; $\mathrm{x}_{1}$ $>30 \%)$ and lower values of hydrolyzed soy protein $\left(\mathrm{x}_{3}<20 \% ; \mathrm{x}_{3}<20 \%\right)$ result in cakes with higher elasticity and cohesiveness, respectively. 
Figure 7 - Contour plots for muffin's gumminess, chewiness and resilience within the trials from the Simplex Centroid Mixture Design.

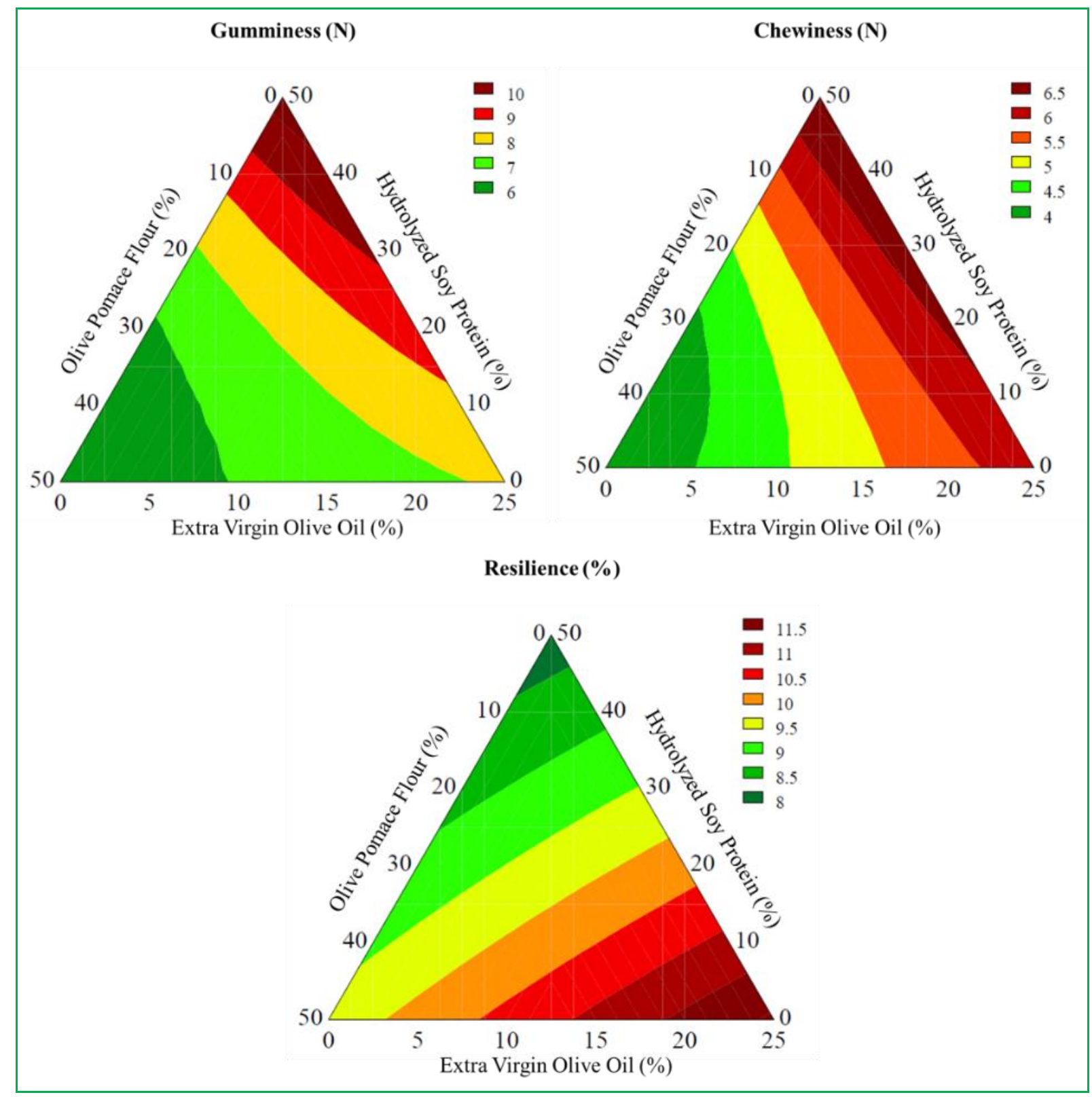

Source: Authors (2022).

The parameters of gumminess (mechanical attribute of texture relative to the cohesiveness of a soft product and has relation to the force required in the mouth to disintegrate the product to the ideal point for swallowing), chewiness (mechanical attribute of texture relative to cohesiveness and time spent, or the number of bites required for a solid product to be ready for swallowing) are directly related to the texture characteristics perceived by the consumers during chewing and swallowing a product (Teotônio et al., 2021).

It was observed that the gumminess ranged between $5.53 \pm 0.47$ and $10.40 \pm 1.26 \mathrm{~N}$. Through the ANOVA, $82.48 \%$ of the results can be explained by the mathematical model $\left(\mathrm{F}_{\text {calc }} / \mathrm{F}_{\text {tab } 3 ; 8 ; 0.10}=4.30 ; P=0.002\right)$. The best effect was observed for the binary combination between olive pomace flour and hydrolyzed soy protein $\left(\beta_{13}=-6.26 ; P=0.092\right)$. By the contour plot for gumminess (Figure 7), it was observed that the combination between these components is favorable in the ranges of $30-$ 
$50 \%$ of olive pomace flour and up to $15 \%$ of hydrolyzed soy protein. This result also indicates that smaller amounts of extra virgin olive oil can help in reducing the crumb gumminess.

The chewiness of the muffins varied between $3.89 \pm 0.47$ and $6.62 \pm 0.81 \mathrm{~N}$ between the trials. According to ANOVA, $73.31 \%$ of the results can be explained by the predictive mathematical model $\left(\mathrm{F}_{\text {calc }} / \mathrm{F}_{\text {tab } 3 ; 8 ; 0.10}=4.30 ; P=0.002\right)$. The binary or ternary combination of the independent variables had no significant effect on the chewiness of the muffins, with the most representative pseudocomponent in the results being hydrolyzed soy protein $\left(\beta_{3}=6.63 ; P<0.001\right)$. According to the contour plot for chewiness (Figure 7), it is understood that between $28-50 \%$ of olive pomace flour and $0-5 \%$ of extra virgin olive oil result in better chewability profiles due to lower values. On the other hand, any content of hydrolyzed soy protein increases chewiness values, which is negative for the texture profile of the muffins.

The data obtained for the resilience of the muffins varied between $7.88 \pm 0.51$ and $11.35 \pm 0.65 \%$. According to the result presented by ANOVA, $95.88 \%$ of the data can be explained by the mathematical model $\left(\mathrm{F}_{\text {calc }} / \mathrm{F}_{\text {tab } 3 ; 8 ; 0.10}=21.25 ; P<\right.$ 0.001). As for chewability, the combination of independent variables did not significantly affect resilience, with extra virgin olive oil being the pseudo component with the most significant effect on this parameter $\left(\beta_{2}=11.58 ; P<0.001\right)$.

Table 8 - Mathematical models for the dependent variables for dough and muffin properties in codified levels with statistical significance $(P<0.10)$.

\begin{tabular}{|c|c|c|}
\hline Dependent variable & Mathematical model & $\overline{\mathbf{R}^{2}}$ \\
\hline Specific gravimetry & $0.73 \mathrm{x}_{1}+0.85 \mathrm{x}_{2}+0.89 \mathrm{x}_{3}-1.89{ }_{2} \mathrm{x}_{3}+4.81 \mathrm{x}_{1} \mathrm{x}_{2} \mathrm{x}_{3}$ & 0.9802 \\
\hline $\mathrm{pH}$ batter & $6.51 \mathrm{x}_{1}+6.09 \mathrm{x}_{2}+5.90 \mathrm{x}_{3}-1.22 \mathrm{x}_{1} \mathrm{x}_{3}$ & 0.7096 \\
\hline $\begin{array}{l}\text { Total titratable acidity } \\
\text { (mg KOH.g }{ }^{-1} \text { sample) }\end{array}$ & $0.65 \mathrm{x}_{1}+0.26 \mathrm{x}_{2}+2.09 \mathrm{x}_{3}+0.39 \mathrm{x}_{1} \mathrm{x}_{2}+0.49 \mathrm{x}_{1} \mathrm{x}_{3}-2.65 \mathrm{x}_{1} \mathrm{x}_{2} \mathrm{x}_{3}$ & 0.9977 \\
\hline $\mathrm{pH}$ muffin & $6.74 \mathrm{x}_{1}+7.12 \mathrm{x}_{2}+6.30 \mathrm{x}_{3}-0.471 \mathrm{x}_{1} \mathrm{x}_{3}-0.87 \mathrm{x}_{2} \mathrm{x}_{3}$ & 0.9802 \\
\hline Variable $L^{*}$ & $38.21 \mathrm{x}_{1}+77.41 \mathrm{x}_{2}+61.01 \mathrm{x}_{3}-37.29 \mathrm{x}_{1} \mathrm{x}_{2}-15.88 \mathrm{x}_{2} \mathrm{x}_{3}$ & 0.9958 \\
\hline Variable $a^{*}$ & $4.98 x_{1}+2.99 x_{2}+11.62 x_{3}-6.90 x_{1} x_{3}+10.80 x_{2} x_{3}-27.92 x_{1} x_{2} x_{3}$ & 0.9955 \\
\hline Variable $b^{*}$ & $13.96 \mathrm{x}_{1}+31.09 \mathrm{x}_{2}+31.82 \mathrm{x}_{3}-25.80 \mathrm{x}_{1} \mathrm{x}_{2}$ & 0.9921 \\
\hline Color difference $(\Delta \mathrm{E})$ & $42.94 \mathrm{x}_{1}+2.42 \mathrm{x}_{2}+19.65 \mathrm{x}_{3}+40.00 \mathrm{x}_{1} \mathrm{x}_{2}-7.24 \mathrm{x}_{1} \mathrm{x}_{3}+18.39 \mathrm{x}_{2} \mathrm{x}_{3}-51.74 \mathrm{x}_{1} \mathrm{x}_{2} \mathrm{x}_{3}$ & 0.9993 \\
\hline Firmness (N) & $11.67 \mathrm{x}_{1}+11.82 \mathrm{x}_{2}+27.62 \mathrm{x}_{3}-20.06 \mathrm{x}_{1} \mathrm{x}_{3}$ & 0.8090 \\
\hline Hardness (N) & $19.90 \mathrm{x}_{1}+19.84 \mathrm{x}_{2}+27.62 \mathrm{x}_{3}-26.81 \mathrm{x}_{1} \mathrm{x}_{3}$ & 0.8399 \\
\hline Springiness $(\%)$ & $67.33 x_{1}+77.44 x_{2}+63.79 x_{3}+71.47 x_{1} x_{2} x_{3}$ & 0.9140 \\
\hline Cohesiveness (\%) & $27.34 \mathrm{x}_{1}+34.87 \mathrm{x}_{2}+23.31 \mathrm{x}_{3}$ & 0.9665 \\
\hline Gumminess (N) & $5.30 \mathrm{x}_{1}+7.15 \mathrm{x}_{2}+10.46 \mathrm{x}_{3}-6.26 \mathrm{x}_{1} \mathrm{x}_{3}$ & 0.8248 \\
\hline Chewiness $(\mathrm{N})$ & $3.53 \mathrm{x}_{1}+5.78 \mathrm{x}_{2}+6.63 \mathrm{x}_{3}$ & 0.7331 \\
\hline Resilience (\%) & $9.20 \mathrm{x}_{1}+11.58 \mathrm{x}_{2}+7.77 \mathrm{x}_{3}$ & 0.9588 \\
\hline
\end{tabular}

$\mathrm{x}_{1}=$ olive pomace flour; $\mathrm{x}_{2}=$ extra virgin olive oil; $\mathrm{x}_{3}=$ hydrolyzed soy protein. Source: Authors (2022).

Evaluating the texture profile analysis of the muffins, it was verified that the combination between olive pomace flour and hydrolyzed soy protein reduces the values of firmness, hardness and gumminess. According to Gentile (2020), the association between protein and polysaccharide allows the formation of a strong amphiphilic conjugate that anchors at the oilwater interface of an emulsion. In this conformation, the binding occurs through the hydrophobic groups of the proteins, creating a viscoelastic layer where the polysaccharide acts as a copolymer, causing steric stabilization and the consequent gelation of the structure.

Marchetti et al. (2021), in a study on the effect of the addition of pecan nut flour on the quality of gluten-free muffins, identified a slight increase in the elasticity and adhesiveness of the muffin as a result of the use of alternative flour in addition to small reductions in the hardness and chewiness and no change in the resilience of the final product.

Martínez-Cervera et al. (2012) obtained lower hardness values in samples with sucrose replacement between $25-50$ $\%$. However, the parameters of elasticity, cohesiveness and chewability decreased significantly and proportionally to the 
increase in sucrose replacement, resulting in a more compact crumb. The authors relate this observation to the retarding effect of sucrose on the gelatinization temperature of starch, which is related to a softening of the muffin.

According to the results obtained, lower extra virgin olive oil levels are required to obtain better texture results. Therefore, at adequate levels, olive pomace flour and hydrolyzed soy protein allow the muffin emulsion stabilization during the baking process. This process can occur by forming hydrogen bonds and ionic interactions between a limited number of polysaccharides and proteins, a reaction favored by the presence of lysine (basic amino acid) in the medium. Indeed, leguminous proteins are known to be rich in lysine, as is the case with hydrolyzed soy protein (Gentile, 2020; Schmiele et al., 2017). In this sense, it was possible to obtain a profile of firmness, hardness and gumminess where the muffin has a soft, light texture, with a good incorporation of air in the dough, resulting in a fine alveolar structure.

Extra virgin olive oil positively influences elasticity, cohesiveness, and resilience parameters. This effect is mainly due to the formation of the batter's emulsified structure and emulsion stability when subjected to baking (Gentile, 2020), as can be seen by the effect on the specific gravity of the dough and the three texture parameters mentioned.

For elasticity and cohesiveness, the best results are associated with low levels of hydrolyzed soy protein and intermediate amounts of olive pomace flour. This indicated that there is a limit where the association between the polysaccharide and the protein results in positive aspects of texture so that high values of these two components can cause the formation of a dense mass, with little incorporation of air, which leads to a hard muffin (externally and internally) and with a "doughy" crumb, as can be seen in Figure 5. This observation is corroborated by the results obtained for the chewability of the muffins. Hydrolyzed soy protein is associated with an increase in the force required to chew a solid since it actively stabilizes the emulsion and gelling properties. Nieto-Mazzocco et al. (2022), in their study on the optimization of gluten-free muffin formulation with agavin-type fruits as a fat and sucrose substitute, observed that lower fat contents increase the elasticity of the final product.

\subsection{Numerical optimization and mathematical models' validation}

The muffin formulation optimization was carried out to obtain the highest incorporation of olive pomace flour since this dependent variable provided essential characteristics such as greater incorporation of air in the batter and soft texture to the crumb. As the extra virgin olive oil presented different results for the technological attributes of the muffins, it was decided to keep this variable in range. The substitution of wheat flour for olive pomace flour diluted the proteins present in the formulation. Allied to this, the presence of soy proteins presents an excellent profile of essential amino acids when combined with cereal proteins. Therefore, a minimum of $10 \%$ of hydrolyzed soy protein in the formulation was aimed to use in the muffin.

For the statistically significant dependent variables $\left(P<0.10 ; \mathrm{F}_{\mathrm{cal}} / \mathrm{F}_{\mathrm{tab}}>1\right.$ and $\left.\mathrm{R}^{2}>0.80\right)$, importance's between 1 and 5 were assigned, with 1 being considered less important and 5 being more important. The target was defined as "maximize" (color difference), "in range" ( $\mathrm{pH}$ and total titratable acidity of the batter and $\mathrm{pH}$, elasticity, cohesiveness, chewability and resilience) and "minimize" ( $L^{*}, a^{*}, b^{*}$, firmness, hardness and gumminess) as shown in Table 9. 
Table 9 - Results for experimental and predictive values and relative deviation regarding the validation of mathematical models.

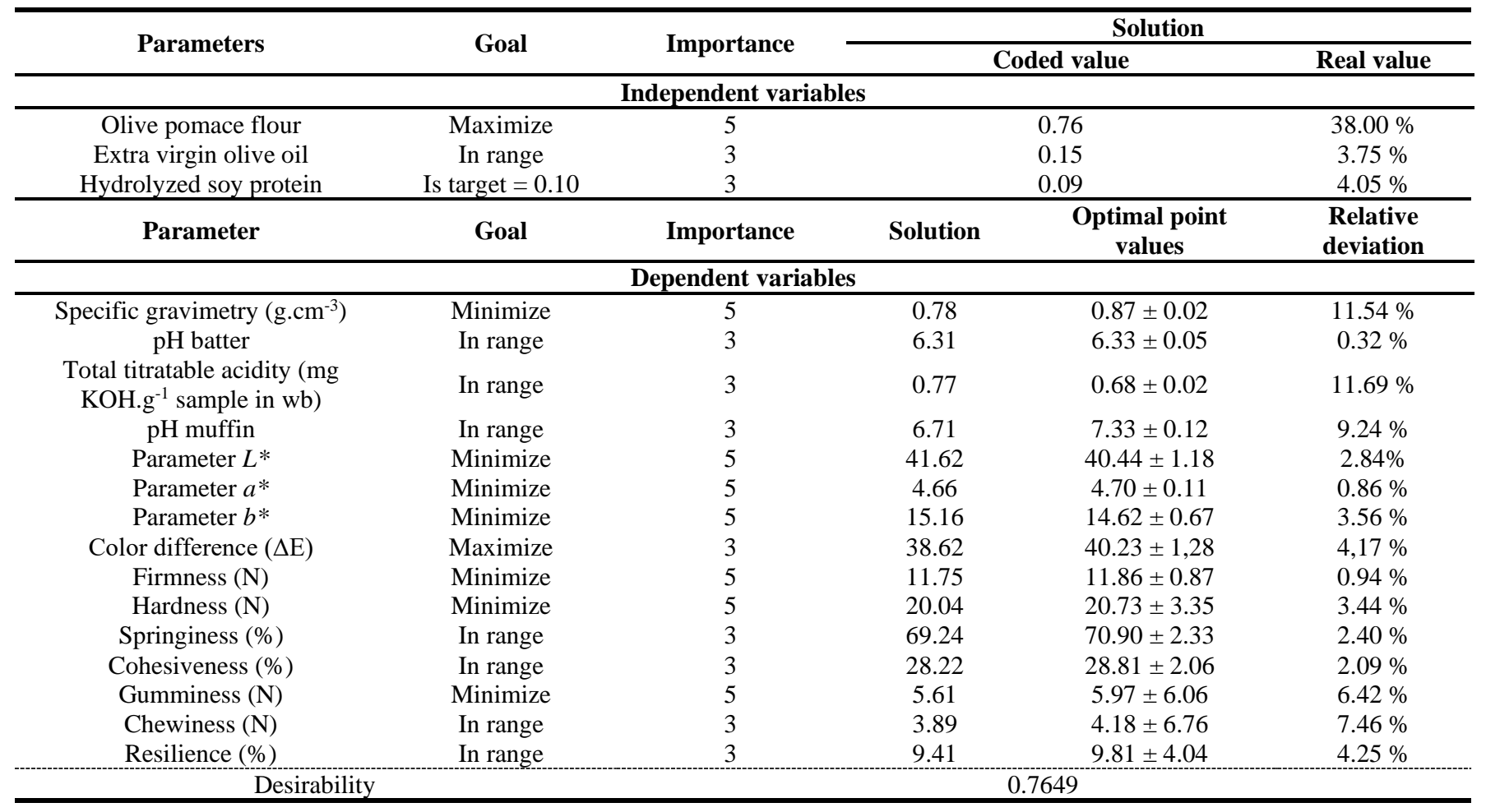

Source: Authors (2022).

The best solution was obtained using $38.00 \%$ olive pomace flour, $3.75 \%$ extra virgin olive oil and $4.05 \%$ hydrolyzed soy protein in partial replacement of wheat flour, hydrogenated vegetable fat and sucrose, respectively. This formulation was processed in true triplicate, and the dependent variables were analyzed to verify the validity of the mathematical models. Under the conditions stipulated, a degree of desirability of $76.49 \%$ was established. In general, it was observed that mathematical models could predict experimental values. It was validated since the relative deviation found was up to $\pm 10 \%$, except for the specific gravity of the batter and the total titratable acidity of the muffin, which presented relative deviations of 11.54 and $11.69 \%$, respectively. In both cases, these values were considered acceptable because as the specific gravity of the batter shows values below 1 , any slight variation during the analysis results in higher values of relative deviation. In the case of total titratable acidity, the value above $10 \%$ for the relative deviation was also accepted and justified by the challenge during the analysis procedure, since the hydrolyzed soy protein has a buffering effect, hindering the view of the color change and the turning point during the sample titration.

\subsection{Chemical composition, total caloric value and image analysis of the alveoli of the slices of the standard sample and optimal point}

The chemical composition (Table 10) results from the contribution of macro and micronutrients of the ingredients and changes resulting from the production process. It was observed that the optimized muffin formulation had higher lipid contents and lower starch levels. In addition, the optimized muffin had a better effect on the composition of minerals of $1.09 \pm 0.01 \%$, total dietary fiber of $11.62 \pm 0.74 \%$ and total phenolic compounds of $88.76 \pm 2.47 \% \mathrm{mg}$ of gallic acid per $100 \mathrm{~g}$ of product. These effects can be attributed to the chemical composition of the substituted ingredients (Table 11). 
Table 10 - Chemical composition of standard and optimal point muffins.

\begin{tabular}{|c|c|c|c|c|}
\hline Parameters & Stardard sample & Optimal point & $\begin{array}{c}\text { Component } \\
\text { difference }(\%)\end{array}$ & p-value \\
\hline Moisture (\%) & $25.18 \pm 0.33$ & $25.31 \pm 0.32$ & 0.52 & 0.633 \\
\hline Proteins $(\%)$ & $7.38 \pm 0.53$ & $7.00 \pm 0.12$ & -5.15 & 0.266 \\
\hline Lipids (\%) & $17.96 \pm 0.10$ & $21.41 \pm 0.11$ & 19.21 & $<0.001$ \\
\hline Ashes $(\%)$ & $0.91 \pm 0.01$ & $1.09 \pm 0.01$ & 19.78 & $<0.001$ \\
\hline Total sugars (\%) & $19.94 \pm 0.65$ & $21.03 \pm 0.71$ & 5.47 & 0.098 \\
\hline Starch $(\%)$ & $22.77 \pm 2.77$ & $12.49 \pm 0.81$ & -45.15 & $<0.001$ \\
\hline Total dietary fiber $(\%)^{*}$ & $5.87 \pm 2.92$ & $11.68 \pm 1.13$ & 98.98 & - \\
\hline $\begin{array}{l}\text { Total phenolic compounds (mg. } 100 \mathrm{~g}^{-} \\
1 \text { of sample) }\end{array}$ & $50.93 \pm 2.27$ & $88.76 \pm 2.47$ & 75.28 & $<0.001$ \\
\hline $\begin{array}{c}\text { Total calories value (kcal per } \\
\text { serving } * *)\end{array}$ & 217 & 213 & -1.84 & - \\
\hline
\end{tabular}

Means of ten repetitions \pm standard deviation. * Standard deviation calculated by propagation error. **According to Brazilian law, one serving of cake corresponds to $60 \mathrm{~g}$ (Brasil, 2012). Source: Authors (2022).

The optimized muffin formula showed higher fiber incorporation and lower starch content. These effects can be attributed to replacing wheat flour with olive pomace flour, which has a high fiber content since it corresponds to the solid portion of the pulp and skin of the olives. On the other hand, wheat flour is mainly a digestible carbohydrate $(68.85 \pm 0.77 \%)$. In addition, the muffin at the optimum point had a higher content of phenolic compounds than the standard muffin, the incorporation of these components can be attributed to the composition of the olive pomace flour (153.87 $\pm 1.31 \mathrm{mg}$ of gallic acid per $100 \mathrm{~g}$ of product) and extra virgin olive oil $c v$. Barnea (14.72 $\pm 1.28 \mathrm{mg}$ of gallic acid per $100 \mathrm{~g}$ of product) (Silva, 2020).

In addition, the muffin produced from the optimized formulation had a higher lipid content due to the residual fat content of olive pomace $(15.40 \pm 0.36 \%)$. However, despite being higher, the added lipid content contributes to the fatty acid composition with a more nutritionally interesting profile due to monounsaturated fatty acids. On the other hand, the superior mineral composition of the optimized muffin can be associated with both the composition of olive pomace flour $(3.02 \pm 0.08$ $\%)$ and that of hydrolyzed soy protein $(9.87 \pm 0.25 \%)$. Fibers and some proteins can be complex with minerals that increase micronutrient content (Damodaran \& Parkin, 2019). Also, substituting ingredients reduced the total caloric value of the optimized muffin in absolute values. However, it is impossible to determine whether the change is statistically significant. Although the muffin of optimal point did not show a statistically significant difference for moisture content, total sugar and protein content regarding the standard sample, the nutritional profile of the amino acids of hydrolyzed soy protein has a more significant dietary advantage.

According to the results, the substitution of ingredients resulted in muffins with a proper nutritional composition due to incorporating total dietary fiber, total phenolic compounds, minerals, lipids and proteins with more interesting profiles, considered essential components to favor the healthiness of the product. In addition, there was a decrease in the levels of starch in the muffin. Furthermore, according to Resolution Collegiate Board $\mathrm{n}^{\circ} 54$ of November 12, 2012, from the National Health Surveillance Agency of the Ministry of Health, the optimized muffin presented a product profile rich in dietary fiber $(>5.0 \mathrm{~g}$ per serving) and increased mineral content (greater than $10 \%$ increase from standard). 
Table 11 - Chemical composition of the raw materials used in the experimental design.

\begin{tabular}{|c|c|c|c|c|c|c|}
\hline \multirow[b]{2}{*}{ Parameters } & \multicolumn{3}{|c|}{ Substituent ingredients } & \multicolumn{3}{|c|}{ Substituted ingredients } \\
\hline & $\begin{array}{c}\text { Olive pomace } \\
\text { flour }\end{array}$ & $\begin{array}{c}\text { Extra virgin } \\
\text { olive oil }\end{array}$ & $\begin{array}{c}\text { Hydrolyzed soy } \\
\text { protein }\end{array}$ & Wheat flour & $\begin{array}{c}\text { Hydrogenated } \\
\text { vegetable fat }\end{array}$ & Sucrose \\
\hline Moisture (\%) & $9.87 \pm 0.25^{\mathrm{b}}$ & nd & $5.84 \pm 0.17^{\mathrm{c}}$ & $11.73 \pm 0.17^{\mathrm{a}}$ & nd & nd \\
\hline Proteins $(\%)$ & $10.65 \pm 0.24^{\mathrm{b}}$ & nd & $66.38 \pm 0.95^{\mathrm{a}}$ & $11.47 \pm 0.38^{\mathrm{b}}$ & nd & nd \\
\hline Lipids (\%) & $15.40 \pm 0.36^{\mathrm{b}}$ & $99.28 \pm 0.33^{\mathrm{a}}$ & nd & $2.85 \pm 0.08^{c}$ & $98.59 \pm 1.02^{\mathrm{a}}$ & nd \\
\hline Ashes (\%) & $3.02 \pm 0.08^{\mathrm{b}}$ & nd & $9.37 \pm 0.15^{\mathrm{a}}$ & $0.70 \pm 0.04^{\mathrm{c}}$ & nd & nd \\
\hline $\begin{array}{c}\text { Total digestible } \\
\text { carbohydrates }(\%)\end{array}$ & nd & nd & nd & $68.85 \pm 0.77^{\mathrm{b}}$ & nd & $98.49 \pm 0.32^{\mathrm{a}}$ \\
\hline $\begin{array}{c}\text { Total dietary fiber } \\
(\%)^{*}\end{array}$ & nd & nd & nd & $4.40 \pm 0.89$ & nd & nd \\
\hline $\begin{array}{l}\text { Total phenolic } \\
\text { compounds } \\
\text { (mg. } 100 \mathrm{~g}^{-1} \text { of } \\
\text { sample) }\end{array}$ & $153.87 \pm 1.31$ & $14.72 \pm 1.28 * *$ & nd & nd & nd & nd \\
\hline
\end{tabular}

Means of ten repetitions \pm standard deviation. $n d=$ not determined. $*$ Standard deviation calculated by propagation error. $* *$ According to data showed by Silva (2020). Different lowercase letters superscript in the row indicates a significant difference by Tukey's test $(P<0.05)$. Source: Authors (2022).

The porous structure of the cakes is obtained by incorporating air in the mixing stage. The air bubbles formed increase in volume with the release of $\mathrm{CO}_{2}$ from the chemical reaction of the baking powder. In addition, the expansion of air bubbles occurs due to the heating of gases during baking, structuring the alveoli (Cauvain, 2015). Therefore, the efficiency in the incorporation and retention of air and the uniform distribution in the batter greatly influences the specific volume, the texture of the crust and crumb, and the porous structure of the muffins, exerting a direct impact on the acceptance by the consumers. According to Table 12, it was possible to observe the porous structure of the standard muffin and the optimized formulation with the unaided eye and the results for the analysis of the alveoli of the slices.

The total area of the slice did not present a statistically significant difference, indicating that the balance of the substituted and substitute ingredients occurred correctly, favoring the incorporation of air and the retention of gases during the production process. The other parameters were influenced by the substitution of ingredients $(P<0.05)$. The optimized muffin presented cells with a larger average size $\left(\mathrm{mm}^{2}\right)$ and a smaller amount of pores per $\mathrm{cm}^{2}$, resulting in a higher percentage of the area of the cells $(\%)$ on the surface of the slice. Furthermore, the air cells of the optimized muffins showed superior circularity. However, the firmness of the muffin produced by the optimized point was lower than the standard sample.

The alveoli count per $\mathrm{cm}^{2}(1622 \pm 329)$ of the optimized muffin was lower and the mean cell size $\left(0.27 \pm 0.03 \mathrm{~mm}^{2}\right)$ was higher than the standard muffin. These effects can be attributed to the coalescence of the air bubbles since the higher dietary fiber content can result in partial disruption of the bubbles. The amount of alveoli is influenced by the formation of air nuclei in the mixing stage and stabilizing the bubbles during the baking. For the optimized muffin, the creaming was carried out with the incorporation of extra virgin olive oil and hydrolyzed soy protein. As the balance between the polar and hydrophobic amino acid profile of the hydrolyzed soy protein has a surfactant property to favor the aeration of the batter, it is possible to infer that it was possible to form the number of small air nuclei desirable for the development of the soft texture characteristic of the cakes.

Furthermore, extra virgin olive oil's physical state helps displace the fat crystals that surround and stabilize the air bubbles (Cauvain, 2015). However, during baking, the decrease in viscosity caused by the incorporation of extra virgin olive oil may have caused the destabilization of the complex and coalescence of the air cells, resulting in the reduction of alveoli since fats have a better plasticity effect on the batter concerning oils. The average size of the cells for the muffin of the 
optimized formulation corroborates the results obtained for the cell count per $\mathrm{cm}^{2}$ since the coalescence of the air cells causes a reduction in the quantity and an increase in the size of the cells.

The percentage of the area of the alveoli $(44.73 \pm 1.40 \%)$ of the muffin at the optimum point was higher than the standard, indicating that the dough presented adequate viscosity for the retention of air bubbles without any escape to the surface during the supply. Furthermore, the greater circularity of the optimized muffin's alveoli $(0.835 \pm 0.005)$ indicated that there did not impede the growth of air cells during the structuring of the muffin. The structure of the cakes is obtained by the gelatinization of the starch and the denaturation of the proteins during the baking. As the optimized muffin had a higher dietary fiber content due to the incorporation of olive pomace flour, the hydrogen bonds of the non-starch polysaccharide fraction with water favored the viscosity of the medium. Consequently, they reduced the water content available for starch gelatinization, resulting in a more significant expansion of air bubbles before crumb structuring (Bigne et al., 2018).

Table 12 - Alveoli analysis of the standard sample and optimal point.

\begin{tabular}{|c|c|c|c|}
\hline \multirow{2}{*}{ Parameters } & \multicolumn{2}{|c|}{ Sample } & \multirow{2}{*}{ p-value } \\
\hline & Standard & Optimal point & \\
\hline Total area of the slice $\left(\mathrm{cm}^{2}\right)$ & $30.58 \pm 2.19$ & $27.34 \pm 3.01$ & 0.103 \\
\hline Alveoli count per $\mathrm{cm}^{2}$ & $2752 \pm 432$ & $1622 \pm 329$ & 0.001 \\
\hline Average size of alveoli $\left(\mathrm{mm}^{2}\right)$ & $0.181 \pm 0.029$ & $0.273 \pm 0.030$ & 0.001 \\
\hline Percentage of alveoli area (\%) & $35.58 \pm 4.28$ & $44.73 \pm 1.40$ & 0.001 \\
\hline Circularity & $0.805 \pm 0.006$ & $0.835 \pm 0.005$ & $<0.001$ \\
\hline Image & & & \\
\hline
\end{tabular}

Means of four repetitions \pm standard deviation. Source: Authors (2022).

\section{Conclusion}

The demand for products that provide health is increasing. To meet this market niche, convenient and sensorially appreciated products can represent vehicles with the potential to add ingredients with nutritional value. Muffins have high consumer acceptability due to their flavor and texture and have been growing and gaining notoriety in the bakery sector. However, muffins are characterized by large amounts of flour, sugar and fat. To develop muffins with an appeal of health and acceptance by consumers, improving the formulation and processing steps is still necessary. Thus, the partial replacement of these ingredients can improve the nutritional quality of the cakes. The incorporation of vegetable bagasse flour, differentiated lipid sources and legume protein are highly viable alternatives in the development of muffins with reduced flour, sugar and fat, providing a solution regarding sensorially and pleasure in consumption, which are challenges in obtaining healthy products.

This study highlights the application and performance evaluation of olive pomace flour, extra virgin olive oil and hydrolyzed soy protein as nutritionally and technologically interesting substitutes, demonstrating the excellent effect by replacing $38.00 \%$ of the wheat flour with olive pomace flour, $3.75 \%$ of the hydrogenated vegetable fat with extra virgin olive oil and $4.05 \%$ of the sucrose with hydrolyzed soy protein. The technological characteristics analyzed by the Surface Response Methodology resulted in the production of muffins with a characteristic color of the substitute ingredients, texture 
improvement and, consequently, a softer product with possible positive acceptance by consumers. Applying a sensory analysis would be decisive to validate the product developed and the study of shelf life. However, the restrictive situation imposed by the Sars-CoV-2 pandemic made this analysis impossible. In addition, there was an increase in the content of total dietary fiber, phenolic compounds, minerals and lipids with a better fatty acid profile and reduced starch. The total caloric value remained similar between the standard sample and the optimal point, with a narrow reduction in absolute values. Therefore, the partial replacement of ingredients proved an exciting alternative, resulting in technological innovations and new bakery products aiming at a healthy diet.

\section{Acknowledgments}

The authors would like to thank the Federal University of Jequitinhonha and Mucuri Valleys (UFVJM) and the Institute of Science and Technology (ICT - UFVJM) for their institutional support. We would also like to thank the National Council for Scientific and Technological Development (CNPq) for the scholarship to E. C. Souza (process 146453/2019-0) and the financial support (Universal project, protocol 424938/2016-2). Furthermore, we extend our thanks to the Coordination for the Improvement of Higher Education Personnel (CAPES) for the financial assistance (founding code 001) and the scholarship to B. S. Silva. Finally, we were also grateful to Dr. Maria do Céu Monteiro Cruz, from the Department of Agronomy (UFVJM), for providing the olives used in this study and HT Nutri (Camaquã - RS) for providing the hydrolyzed soy protein.

\section{References}

AACCI. (2010). American Association of Cereal Chemists International. Approved Methods of American Association of Cereal Chemists. (11th ed.) AACC, St. Paul.

ABIMAPI -Associação Brasileira de Indústrias de Biscoitos, Massa alimentícias, Pães \& Bolos Industrializados. (2021). Anuário ABIMAPI 2021. São Paulo: BB Editora.

Association of Official Analytical Chemists. (2019). Association of Official Analysis Chemists International (21th ed). USA: AOAC International.

Ahmad-Qasem, M. H., Barrajon-Catalan, E., Micol, V., Cárcel, J. A., \& Garcia-Perez, J. V. (2013). Influence of air temperature on drying kinetics and antioxidant potential of olive pomace. Journal of Food Engineering, 119(3), 516-524. https://doi.org/10.1016/j.jfoodeng.2013.06.027

Al-Bachir, M. (2017). Comparison of fruit characteristics, oil properties and fatty acid composition of local Syrian Kaissy cv olive (Olea europaea). Journal of Food Measurement and Characterization, 11(3), 1011-1018. https://doi.org/10.1007/s11694-017-9476-7

Aparicio-Ruiz, R., \& Gandul-Rojas, B. (2014). Decoloration kinetics of chlorophylls and carotenoids in virgin olive oil by autoxidation. Food Research International, 65, 199-206. https://doi.org/10.1016/j.foodres.2014.05.046

Aranibar, C., Aguirre, A., \& Borneo, R. (2019). Utilization of a by-product of chia oil extraction as a potential source for value addition in wheat muffins. Journal of Food Science and Technology, 56(9), 4189-4197. https://doi.org/10.1007/s13197-019-03889-1

Arrizabalaga-Larrañaga, A., Santos, F. J., \& Moyano, E. (2021). Liquid Chromatography Pigment Profile for Characterization and Fraud Detection in Olive Oils (p. 21-41). https://doi.org/10.1142/9781786349972_0002

Ashaolu, T. J. (2020). Health Applications of Soy Protein Hydrolysates. International Journal of Peptide Research and Therapeutics, 26(4), 2333-2343. https://doi.org/10.1007/s10989-020-10018-6

Ballus, C. A., Quirantes-Piné, R., Bakhouche, A., Silva, L. F. de O., de Oliveira, A. F., Coutinho, E. F., \& Godoy, H. T. (2015). Profile of phenolic compounds of Brazilian virgin olive oils by rapid resolution liquid chromatography coupled to electrospray ionisation time-of-flight mass spectrometry (RRLC-ESI-TOFMS). Food Chemistry, 170, 366-377. https://doi.org/10.1016/j.foodchem.2014.08.054

Bigne, F., Puppo, M. C., \& Ferrero, C. (2018). Mesquite (Prosopis alba) flour as a novel ingredient for obtaining a "panettone-like" bread. Applicability of part-baking technology. $L W T, 89,666-673$. https://doi.org/10.1016/j.lwt.2017.11.029

Cáceres, P. J., Martínez-Villaluenga, C., Amigo, L., \& Frias, J. (2014). Maximising the phytochemical content and antioxidant activity of Ecuadorian brown rice sprouts through optimal germination conditions. Food Chemistry, 152, 407-414. https://doi.org/10.1016/j.foodchem.2013.11.156

Cauvain, S. (2015). Technology of Breadmaking (third). Cham: Springer International Publishing. https://doi.org/10.1007/978-3-319-14687-4

Cedola, A., Cardinali, A., D’Antuono, I., Conte, A., \& Del Nobile, M. A. (2020). Cereal foods fortified with by-products from the olive oil industry. Food Bioscience, 33, 100490. https://doi.org/10.1016/j.fbio.2019.100490

Chen, C., Sun-Waterhouse, D., Zhang, Y., Zhao, M., \& Sun, W. (2020). The chemistry behind the antioxidant actions of soy protein isolate hydrolysates in a 
liposomal system: Their performance in aqueous solutions and liposomes. Food Chemistry, 323, 126789. https://doi.org/10.1016/j.foodchem.2020.126789

Clodoveo, M. L., Crupi, P., Annunziato, A., \& Corbo, F. (2021). Innovative Extraction Technologies for Development of Functional Ingredients Based on Polyphenols from Olive Leaves. Foods, 11(1), 103. https://doi.org/10.3390/foods11010103

Damodaran, S., \& Parking, K. L. (2017). Fennema's Food Chemistry, Fifth Edition. CRC Press. https://doi.org/10.1201/9781315372914

Expósito-Díaz, A., Miho, H., Ledesma-Escobar, C. A., Moral, J., Díez, C. M., \& Priego-Capote, F. (2022). Influence of genetic and interannual factors on bioactive compounds of olive pomace determined through a germplasm survey. Food Chemistry, 378 , 132107. https://doi.org/10.1016/j.foodchem.2022.132107

Filoda, P. F., Chaves, F. C., Hoffmann, J. F., \& Rombaldi, C. V. (2021). Olive oil: a review on the identity and quality of olive oils produced in Brazil. Revista Brasileira de Fruticultura, 43(3). https://doi.org/10.1590/0100-29452021847

Gentile, L. (2020). Protein-polysaccharide interactions and aggregates in food formulations. Current Opinion in Colloid \& Interface Science, 48, 18-27. https://doi.org/10.1016/j.cocis.2020.03.002

Goswami, D., Gupta, R. K., Mridula, D., Sharma, M., \& Tyagi, S. K. (2015). Barnyard millet based muffins: Physical, textural and sensory properties. LWT Food Science and Technology, 64(1), 374-380. https://doi.org/10.1016/j.lwt.2015.05.060

Grasso, S., Liu, S., \& Methven, L. (2020). Quality of muffins enriched with upcycled defatted sunflower seed flour. LWT, 119, 108893. https://doi.org/10.1016/j.1wt.2019.108893

Hayta, M., Benli, B., İşçimen, E. M., \& Kaya, A. (2020). Optimization of antihypertensive and antioxidant hydrolysate extraction from rice bran proteins using ultrasound assisted enzymatic hydrolysis. Journal of Food Measurement and Characterization, 14(5), 2578-2589. https://doi.org/10.1007/s11694-020-005042

IBGE. (2019). Instituto Brasileiro de Geografia e Estatística. Pesquisa Industrial Anual: Produto. Brasil. 2019. https://sidra.ibge.gov.br/Tabela/7752.

Leal, F. H. P. N., Senna, C. de A., Kupski, L., Mendes, G. da R. L., \& Badiale-Furlong, E. (2021). Enzymatic and extrusion pretreatments of defatted rice bran to improve functional properties of protein concentrates. International Journal of Food Science \& Technology, 56(11), 5445-5451. https://doi.org/10.1111/ijfs. 15017

Lechhab, T., Lechhab, W., Cacciola, F., \& Salmoun, F. (2022). Sets of internal and external factors influencing olive oil (Olea europaea L.) composition: a review. European Food Research and Technology. https://doi.org/10.1007/s00217-021-03947-z

Liang, G., Chen, W., Qie, X., Zeng, M., Qin, F., He, Z., \& Chen, J. (2020). Modification of soy protein isolates using combined pre-heat treatment and controlled enzymatic hydrolysis for improving foaming properties. Food Hydrocolloids, 105, 105764. https://doi.org/10.1016/j.foodhyd.2020.105764

Lin, S., Chi, W., Hu, J., Pan, Q., Zheng, B., \& Zeng, S. (2017). Sensory and nutritional properties of chinese olive pomace based high fibre biscuit. Emirates Journal of Food and Agriculture, 495. https://doi.org/10.9755/ejfa.2016-12-1908

Ma, W., Qi, B., Sami, R., Jiang, L., Li, Y., \& Wang, H. (2018). Conformational and Functional Properties of Soybean Proteins Produced by ExtrusionHydrolysis Approach. International Journal of Analytical Chemistry, 2018, 1-11. https://doi.org/10.1155/2018/9182508

Marchetti, L., Acuña, M. S., \& Andrés, S. C. (2021). Effect of pecan nut expeller meal on quality characteristics of gluten-free muffins. LWT, $146,111426$. https://doi.org/10.1016/j.lwt.2021.111426

Martínez-Cervera, S., Sanz, T., Salvador, A., \& Fiszman, S. M. (2012). Rheological, textural and sensorial properties of low-sucrose muffins reformulated with sucralose/polydextrose. LWT - Food Science and Technology, 45(2), 213-220. https://doi.org/10.1016/j.1wt.2011.08.001

Marx, Í. M. G., Rodrigues, N., Veloso, A. C. A., Casal, S., Pereira, J. A., \& Peres, A. M. (2021). Effect of malaxation temperature on the physicochemical and sensory quality of cv. Cobrançosa olive oil and its evaluation using an electronic tongue. LWT, 137, 110426. https://doi.org/10.1016/j.lwt.2020.110426

Matemu, A., Nakamura, S., \& Katayama, S. (2021). Health Benefits of Antioxidative Peptides Derived from Legume Proteins with a High Amino Acid Score. Antioxidants, 10(2), 316. https://doi.org/10.3390/antiox1002031

Medeiros, R. M. L., Villa, F., Silva, D. F., \& Júlio, L. R. C. (2016). Destinação e Reaproveitamento de Subprodutos da Extração Olivícola. Scientia Agraria Paranaensis, 15(2), 100-108. https://doi.org/10.18188/1983-1471/sap.v15n2p100-108

Mokrzycki, W., \& Tatol, M. (2011). Color difference Delta E - A survey. Machine Graphics and Vision, $20(4), 383-411$.

Mozafarpour, R., Koocheki, A., Milani, E., \& Varidi, M. (2019). Extruded soy protein as a novel emulsifier: Structure, interfacial activity and emulsifying property. Food Hydrocolloids, 93, 361-373. https://doi.org/10.1016/j.foodhyd.2019.02.036

Neves, E. C. A., Moysés, B. A., Neves, D. A., Campelo, P. H., \& Clerici, M. T. P. S. (2021). Sustainable and regional gastronomy: cassava leaves as a potential ingredient for gluten-free biscuits. Research, Society and Development, 10(3), e12010313071. https://doi.org/10.33448/rsd-v10i3.13071

Nieto-Mazzocco, E., Saldaña-Robles, A., Franco-Robles, E., Mireles-Arriaga, A. I., Mares-Mares, E., \& Ozuna, C. (2022). Optimization of gluten-free muffin formulation with agavin-type fructans as fat and sucrose replacer using response surface methodology. Future Foods, 5, 100112. https://doi.org/10.1016/j.fufo.2021.100112

Nunes, M. A., Pawlowski, S., Costa, A. S. G., Alves, R. C., Oliveira, M. B. P. P., \& Velizarov, S. (2019). Valorization of olive pomace by a green integrated approach applying sustainable extraction and membrane-assisted concentration. Science of The Total Environment, 652, $40-47$. https://doi.org/10.1016/j.scitotenv.2018.10.204 
Nunes, M. A., Pimentel, F. B., Costa, A. S. G., Alves, R. C., \& Oliveira, M. B. P. P. (2016). Olive by-products for functional and food applications: Challenging opportunities to face environmental constraints. Innovative Food Science \& Emerging Technologies, 35, 139-148. https://doi.org/10.1016/j.ifset.2016.04.016

Nunzio, M., Picone, G., Pasini, F., Chiarello, E., Caboni, M. F., Capozzi, F., ... Bordoni, A. (2020). Olive oil by-product as functional ingredient in bakery products. Influence of processing and evaluation of biological effects. Food Research International, 131, 108940. https://doi.org/10.1016/j.foodres.2019.108940

Pereira, A. S., Shitsuka, D. M., Pereira, F. J., \& Shitsuka, R. (2018). Metodologia da pesquisa científica. UFSM.

Resolução da Diretoria Colegiada n. 54, de 12 de novembro de 2012. Dispõe sobre o Regulamento Técnico sobre Informação Nutricional Complementar. https://bvsms.saude.gov.br/bvs/saudelegis/anvisa/2012/rdc0054_12_11_2012.html.

Rodrigues, F., Pimentel, F. B., \& Oliveira, M. B. P. P. (2015). Olive by-products: Challenge application in cosmetic industry. Industrial Crops and Products, 70, 116-124. https://doi.org/10.1016/j.indcrop.2015.03.027

Rodrigues, M. I., \& Iemma, A. F. (2014). Experimental design and process optimization. CRC Press.

Santos, J. L., Gomes, L. R., Neves, N. de A., \& Schmiele, M. (2022). Desenvolvimento de barra de cereais com aproveitamento de resíduo de mosturação de cerveja desidratado e incorporação de proteína hidrolisada de soja e gelatina. Research, Society and Development, 11(2), e8811225572. https://doi.org/10.33448/rsd-v11i2.25572

Scarton, M., Nascimento, G. C., Felisberto, M. H. F., Moro, T. de M. A., Behrens, J. H., Barbin, D. F., \& Clerici, M. T. P. S. (2021). Muffin with pumpkin flour: technological, sensory and nutritional quality. Brazilian Journal of Food Technology, 24. https://doi.org/10.1590/1981-6723.22920

Scherer, R., \& Böckel, W. J. (2018). Avaliação dos teores de ácidos graxos presentes em azeites de oliva extra virgem comercializados no vale do Taquari. Revista Destaques Acadêmicos, 10(4). https://doi.org/10.22410/issn.2176-3070.v10i4a2018.2041

Schmiele, M., Ferrari Felisberto, M. H., Pedrosa Silva Clerici, M. T., \& Chang, Y. K. (2017). Mixolab ${ }^{\mathrm{TM}}$ for rheological evaluation of wheat flour partially replaced by soy protein hydrolysate and fructooligosaccharides for bread production. LWT - Food Science and Technology, 76, 259-269. https://doi.org/10.1016/j.lwt.2016.07.014

Silva, B. S., \& Schmiele, M. (2021). From olive to olive oil: a general approach. Research, Society and Development, 10(3), e32210313408. https://doi.org/10.33448/rsd-v10i3.13408

Silva, B. S. (2020). Caracterização dos frutos e dos azeites de olivas produzidas em Diamantina (MG) e cinética de secagem dos bagaços. (Dissertação de Mestrado). Universidade Federal dos Vales do Jequitinhonha e Mucuri, Diamantina, MG, Brasil. http://acervo.ufvjm.edu.br/jspui/handle/1/2444.

Silva, B. S., Silva, I. N., Ribeiro, Q. M., Wagner, R., \& Schmiele, M. (2019). Determination of fatty acids composition of extra virgin olive oils and pomace oil produced in Diamantina, Minas Gerais. Trabalho apresentado em Anais do $13^{\circ}$ Simpósio Latino Americano de Ciência de Alimentos.

Silva, J. D. R., Rosa, G. C., Neves, N. de A., Leoro, M. G. V., \& Schmiele, M. (2021). Production of sourdough and gluten-free bread with brown rice and carioca and cowpea beans flours: biochemical, nutritional and structural characteristics. Research, Society and Development, 10(16), e303101623992. https://doi.org/10.33448/rsd-v10i16.23992

Simanca-Sotelo, M., De Paula, C., Domínguez-Anaya, Y., Pastrana-Puche, Y., \& Álvarez-Badel, B. (2021). Physico-chemical and sensory characterization of sweet biscuits made with Yacon flour (Smallanthus sonchifolius). NFS Journal, 22, 14-19. https://doi.org/10.1016/j.nfs.2020.12.001

Sinrod, A. J. G., Avena-Bustillos, R. J., Olson, D. A., Crawford, L. M., Wang, S. C., \& McHugh, T. H. (2019). Phenolics and Antioxidant Capacity of Pitted Olive Pomace Affected by Three Drying Technologies. Journal of Food Science, 84(3), 412-420. https://doi.org/10.1111/1750-3841.14447

Sociedade Brasileira de Alimentação e Nutrição (2016). O benefício do consumo da proteína isolada de soja nas diferentes fases da vida. http://www.sban.org.br/documentos-tecnicos-interno.aspx?post=1.

Souza, A. R., \& Schmiele, M. (2021). Custard apple puree, fructooligosaccharide and soy protein hydrolysate as alternative ingredients in low carb pound cake. Journal of Food Science and Technology, 58(9), 3632-3644. https://doi.org/10.1007/s13197-021-05155-9

Tasiguano, B. L., Villarreal, C., Schmiele, M., \& Vernaza, M. G. (2019). Efecto del tiempo de Cocción del Zapallo (Cucurbita maxima) y la adición de Glucosa Oxidasa en el Aumento de Almidón Resistente del Pan de Molde. Información tecnológica, 30(3), 167-178. https://doi.org/10.4067/S071807642019000300167

Teotônio, D. O., Rodrigues, S. M., Leoro, M. G. V., Pereira, P. A. P., \& Schmiele, M. (2021). Potentialities of using cryoprotectants in gluten-free frozen dough and microwave baking as an emerging technology. Research, Society and Development, 10(6), e12410615674. https://doi.org/10.33448/rsdv10i6.15674

Wang, Y., Yu, L., Zhao, A., Karrar, E., Zhang, H., Jin, Q., \& Wang, X. (2021). Quality Characteristics and Antioxidant Activity during Fruit Ripening of Three Monovarietal Olive Oils Cultivated in China. Journal of the American Oil Chemists' Society, 98(3), 229-240. https://doi.org/10.1002/aocs.12449

Wong, D. W. S. (2018). Mechanism, and Theory in Food Chemistry. Springer International Publishing. 